INTER NATIONAL MONETARY FUND
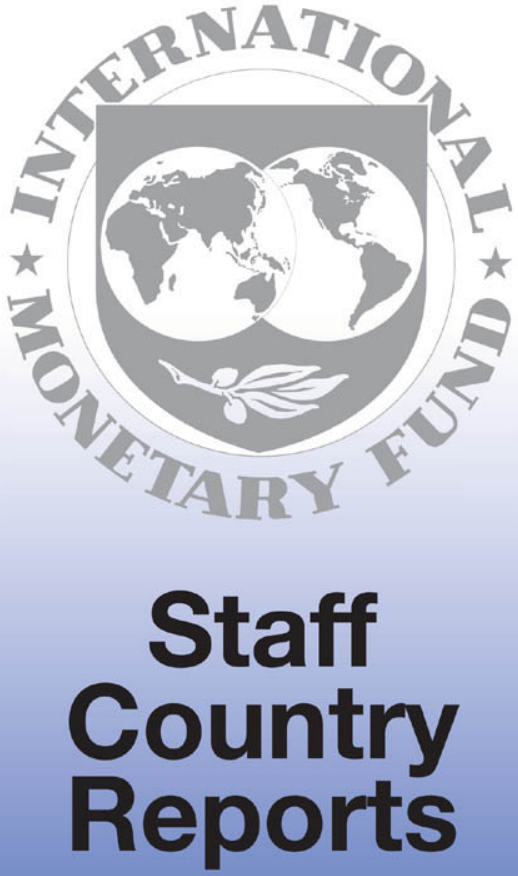


\section{Austria: 2001 Article IV Consultation-Staff Report and Public Information Notice on the Executive Board Consideration}

Under Article IV of the IMF's Articles of Agreement, the IMF holds bilateral discussions with members, usually every year. In the context of the 2001 Article IV consultation with Austria, the following documents have been released and are included in this package:

- the staff report for the 2001 Article IV consultation, prepared by a staff team of the IMF, following discussions that ended on April 3, 2001 with the officials of Austria on economic developments and policies. Based on information available at the time of these discussions, the staff report was completed on May 29, 2001. The views expressed in the staff report are those of the staff team and do not necessarily reflect the views of the Executive Board of the IMF.

- a Public Information Notice ( $\mathrm{PLN}$ ), which summarizes the views of the Executive Board of June 11,2001 in considering the staff report that concluded the Article IV consultation.

The document listed below have been or will be separately released.

Mission Concluding Statement

The policy of publication of staff reports and other documents by the IMF allows for the deletion of market-sensitive information.

To assist the IMF in evaluating the publication policy, reader comments are invited and may be sent by e-mail to Publicationpolicy@imf.org.

Copies of this report are available to the public from

International Monetary Fund - Publication Services

700 19th Street, N.W. - Washington, D.C. 20431

Telephone: (202) 6237430 - Telefax: (202) 6237201

E-mail: publications@imf.org • internet: http://www.imf.org

Price: $\$ 15.00$ a copy

International Monetary Fund

Washington, D.C. 
This page intentionally left blank

(CInternational Monetary Fund. Not for Redistribution 


\section{INTERNATIONAL MONETARY FUND}

\section{AUSTRIA \\ Staff Report for the 2001 Article IV Consultation}

Prepared by the Staff Representatives for the 2001 Consultation with Austria

Approved by C. M. Watson and G. Russell Kinçaid

May 29, 2001

The 2001 Article IV consultation discussions were held in Vienna during March 23April 3, 200l. The mission comprised Messrs. Flickenschild (Head), Eskesen, Vocke, and Ms. Krajnyák (all EU1). Mr. Prader, Alternate Executive Director for Austria, attended the meetings. The mission met with the Ministers of Finance and Economic Affairs and Labor; the Governor of the Austrian National Bank (OeNB); other officials of the federal administration and the OeNB; the chairmen of the federal debt commission and the parliamentary budget committee; the leader of the federation of trade unions; and representatives from the lower levels of government, the chamber of industry, the banking sector, the academic community, and the main economic research institutes.

Austria has accepted the obligations of Article VIII and maintains an exchange system that is free of restrictions on payments and transfers for international transactions (Appendix II). Austria publishes comprehensive economic statistics that are generally adequate for surveillance, although the timeliness and quality could be improved in some areas (Appendix III). Austria subscribes to the SDDS, but has availed itself of flexibility options with respect to the timeliness for foreign trade and industrial production data.

At the conclusion of the last Article IV consultation on August 3, 2000, Executive Directors commended Austria's good inflation, growth, and labor market performance, and welcomed the authorities' plans to accelerate and strengthen their fiscal consolidation effort. They also encouraged the authorities to increase the flexibility of goods and labor markets and welcomed their intention to sell government holdings in commercial enterprises.

A center-right coalition government took office in February 2000, ending half a century of center-left consensus politics. In reaction to the inclusion of the Freedom Party (FPO) in the government, Austria's EU partners imposed bilateral political sanctions against Austria, which were lifted in September 2000.

The authorities released the mission's preliminary conclusions to the public and have again agreed to publish this staff report. In light of the reasonably favorable economic outlook and the absence of acute economic problems facing Austria, this staff report is circulated to the Executive Board on a lapse-of-time basis. 


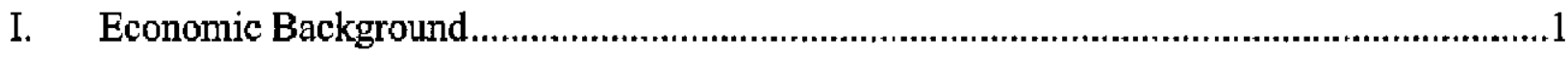

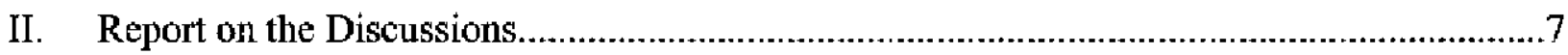

A. The Short-Term Policy Stance .............................................................................1 1

B. Fiscal Adjustment - Composition and Risks .....................................................11

C. Medium- and Long-Term Fiscal Issues ..........................................................14

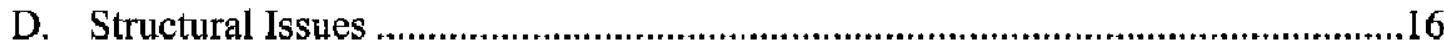

E. Financial Sector Issues .......................................................................................19

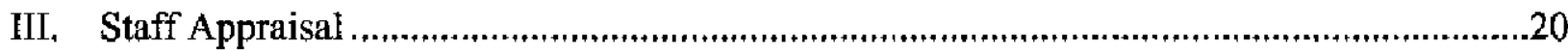

Tables

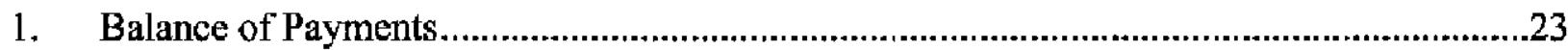

2. General Government Finances - National Accounts Basis .................................................24

3. $\quad$ Fiscal Projections Based on the 2001-2004 Stability Program ..........................................25

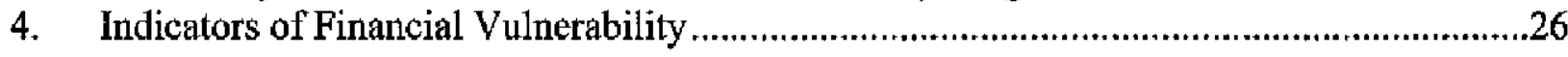

Text Boxes

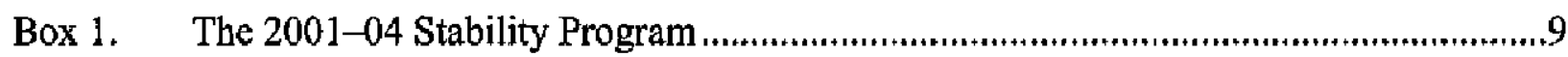

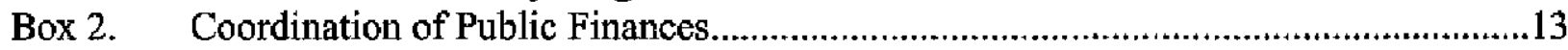

\section{Figures}

1. Output, Inflation and Unemployment in Austria and European Union .................................3

2. Components of Current Account .........................................................................................4

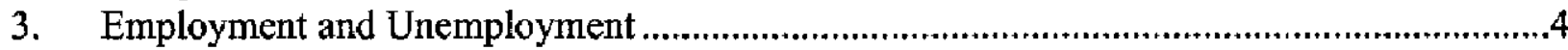

4. Inflation Rate in Austria and the Euro Area ................................................................

5. Output Gap, Fiscal Impulse, and Monetary Conditions ....................................................

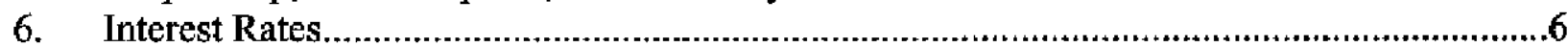

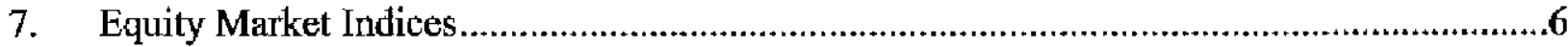

8. $\quad$ Effective Exchange Rates ......................................................................................................

9. Contribution of Demand Components to Real GDP Growth ..................................................

10. Euro Area: Fiscal Balances (Actual and Targeted), Expenditure Ratios,

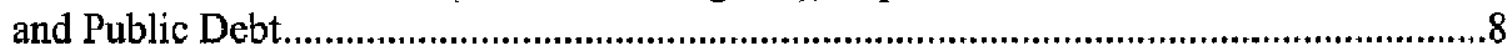

11. Cross Country Comparison of Labor Force Participation Rate, 55-64 Cohort, 1999 _........15

12. Cross Country Comparison of Prices.................................................................................17

Appendices

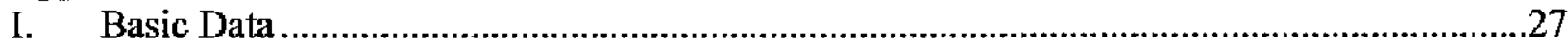

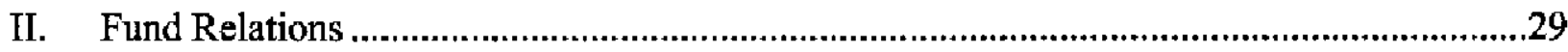

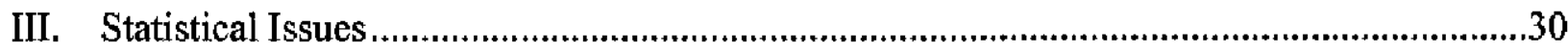




\section{ECONOMIC BACKGROUND}

\section{The Austrian economy performed solidly in the 1990s despite slow fiscal} adjustment and lagging structural reforms. Per capita economic growth averaged 1.8 percent per annum, and the unemployment and inflation rates were among the lowest in the EU (Figure 1). Economic activity benefited from Austrian firms' early involvement in the restructuring of the neighboring central and east European countries (CEECs). Further benefits can be expected from increasing integration as the CEECs prepare for EU membership. In the labor market, a long-standing social partnership helped ensure wage moderation and contain unemployment while keeping labor relations peaceful.

Figure 1. Cutput, Inflation, and Unemployment in Austria and European Union
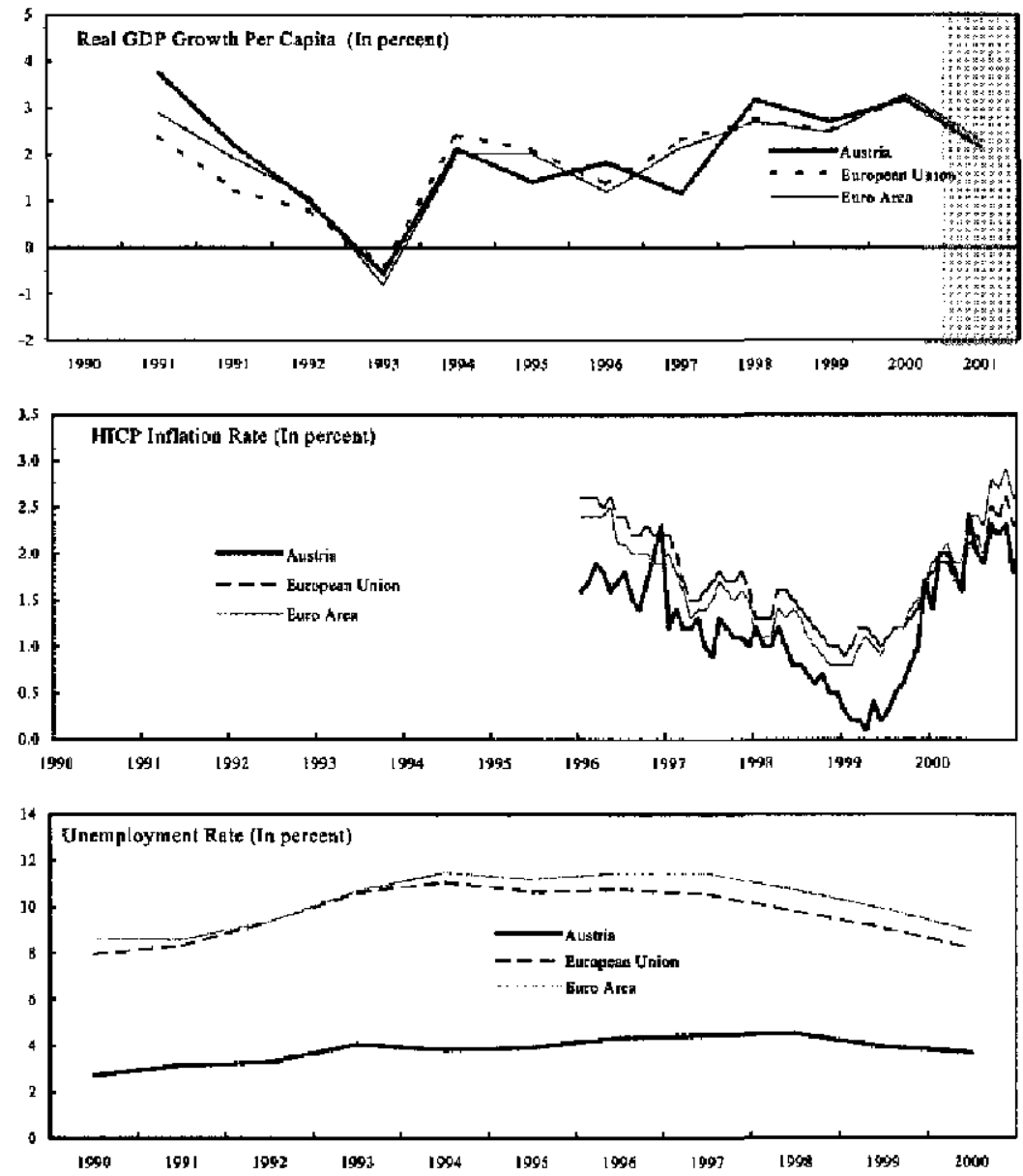

Source: lhH, Warkl Eenonumic Outleot; and Eurastat. 
2. Real GDP growth picked up to 3.2 percent in 2000. After a brief slowdown in the aftermath of the Asian crisis, brisk activity resumed in mid1999 with a rebound of exports and investment. The upswing became more broadly based when consumption picked up later in 1999, and--boosted by the effects of the 1999 tax reformstrengthened further in early 2000 . Helped by a favorable external environment, growth accelerated to $3 \frac{1}{2}-4$ percent in the first half of 2000 before weakening in tandem with external demand. Despite higher oil prices, the current account deficit narrowed slightly, from 3.2 percent of GDP in 1999 to 2.9 percent in 2000 , reflecting strong export growth and lower transfers to the EU (Figure 2).

Figure 2. Austria: Components of Current Account (In percent of GDP)

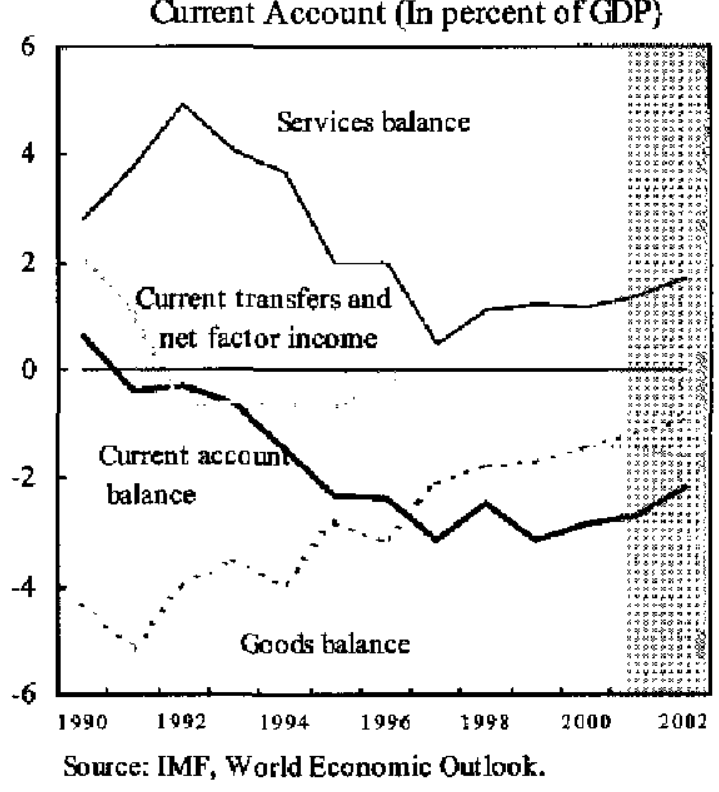

\section{Unemployment declined to 3.7 percent in March 2001, and inflation continues to} remain slightly below the euro area average (Figures 3 and 4). Benefiting from the strength of domestic demand, employment rose by 1 percent in 2000 , mostly in the service sector. Although certain segments of the labor market appear tight (e.g., in the information technology sector), recent wage agreements do not indicate a significant increase in wage pressures. The sharp increase in oil prices pushed harmonized annual inflation to 2 percent (12-month inflation peaked at 2.3 percent in November 2000 and stood at 2 percent in March 2001), but antual underlying inflation remained at around 1 percent, benefiting from wage moderation and stronger competition in newly liberalized sectors (electricity and telecom).

Figure 3. Austria: Employment and

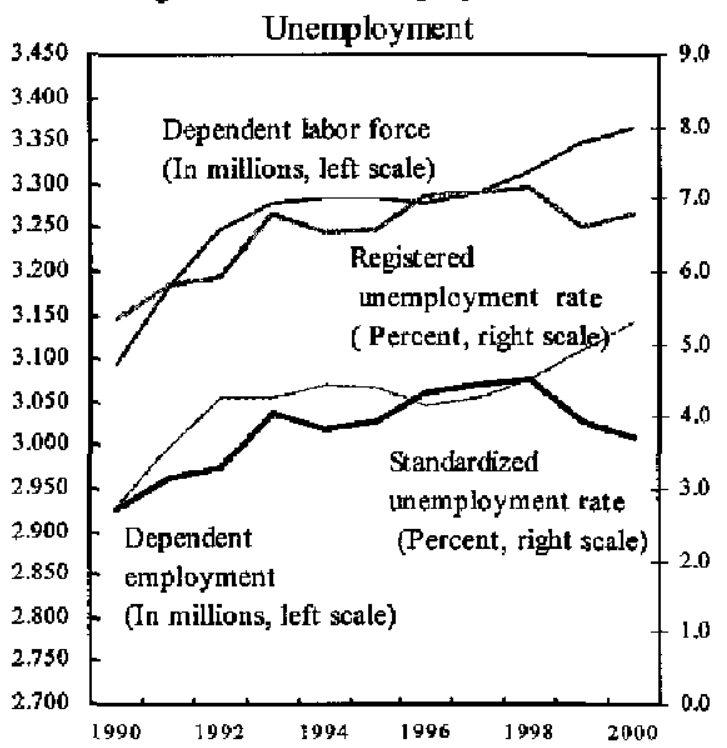

Source: IMF, World Economic Outlook.
Figure 4. Inflation Rate in Austria and the Euro Area

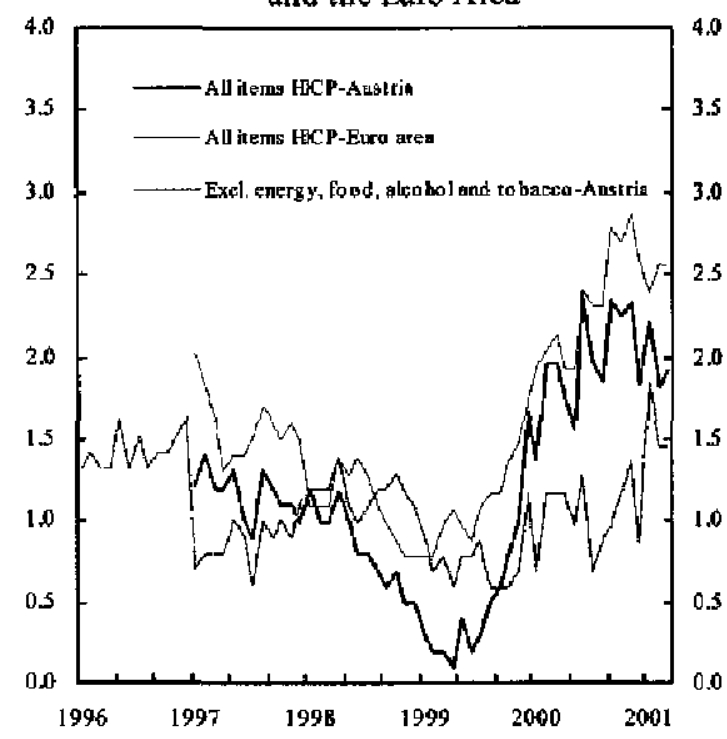

Source: Eurostat. 


\section{A broadly neutral fiscal policy stance and somewhat firmer monetary conditions} resulted in a slightly contractionary policy mix in 2000 (Figure 5). The general government posted a deficit of 1.1 percent of GDP, a Figure 5. Austria: Output Gap, Fiscal Impulse, and Monetary Conditions full percentage point lower than in 1999 and about 0.6 percent of GDP smaller than budgeted. However, virtually all of the improvement in 2000 can be attributed to cyclical and one-off factors. Strong growth buoyed tax revenues by about $1 / 4$ percent of GDP, while lower interest payments and revenues from sales of assets and UMTS licenses (considered negative expenditures in ESA95) reduced expenditures by $1 / 4$ and $1 / 2$ percent of GDP, respectively. The fiscal impulse (defined as the change in the adjusted primary structural balance) is estimated to have been around zero. Meanwhile, monetary conditions for Austria firmed slightly, dominated by the effects of higher interest rates due to increases in the ECB's repo rate, but remained supportive overall (Figure 6). The Vienna stock exchange maintained its low valuation level, while other European markets dropped sharply from recent highs (Figure 7).
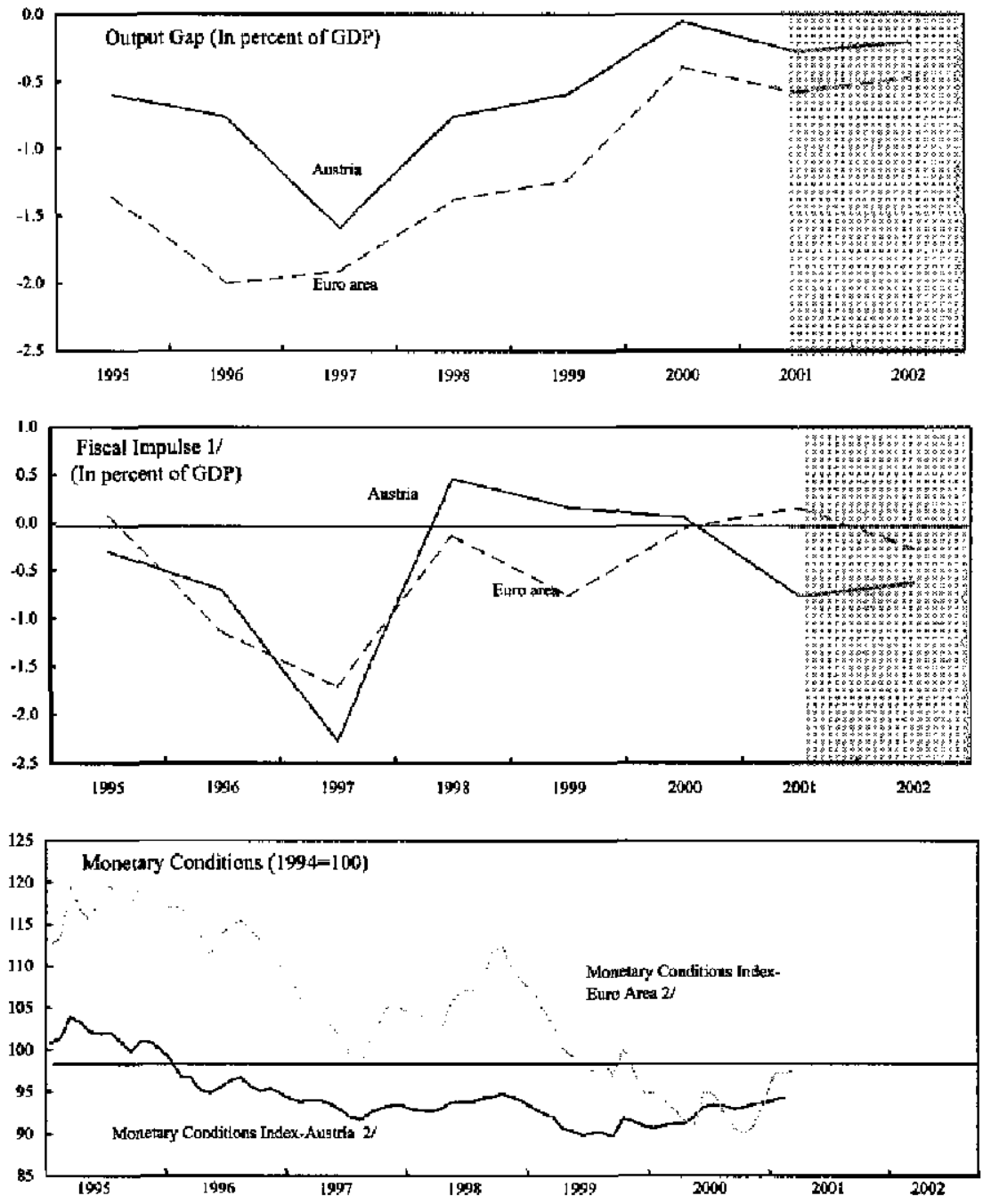

Source: IMF, World Economic Outlook; Intemational Finance Statistics; and staff estimates. $1 /$ Change in structeral primary balsnce; in the case of Austtia adjusted for sale of mobile phone lieenses and real estate and net subsidjzed lending.

2/ Weighted average of real short-term interest rates and real effective exchange rate (weighte: 3 and 1 . respeetively). 
Figure 6. Austria: Interest Rates

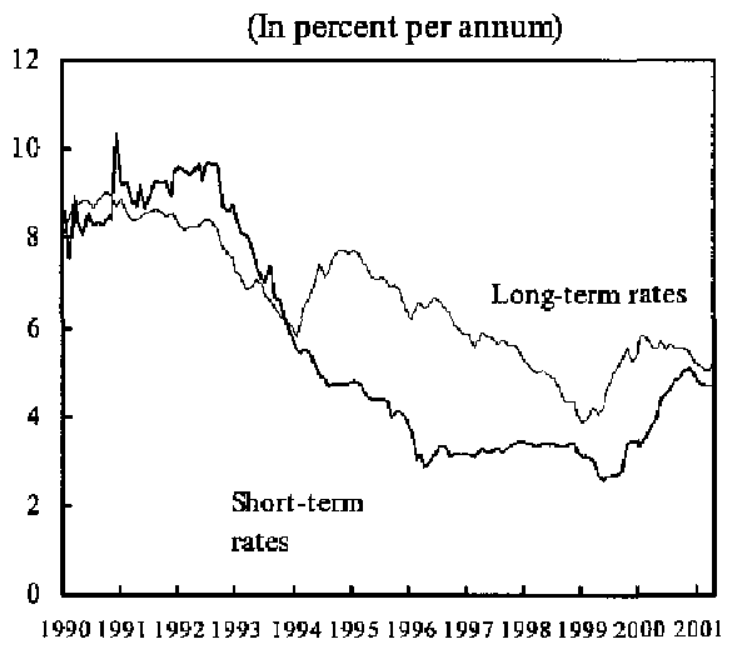

Source: IMF, International Finance Statistics; and WEFA database.
Figure 7. Equity Market Indices

(January 4, 1999=100)

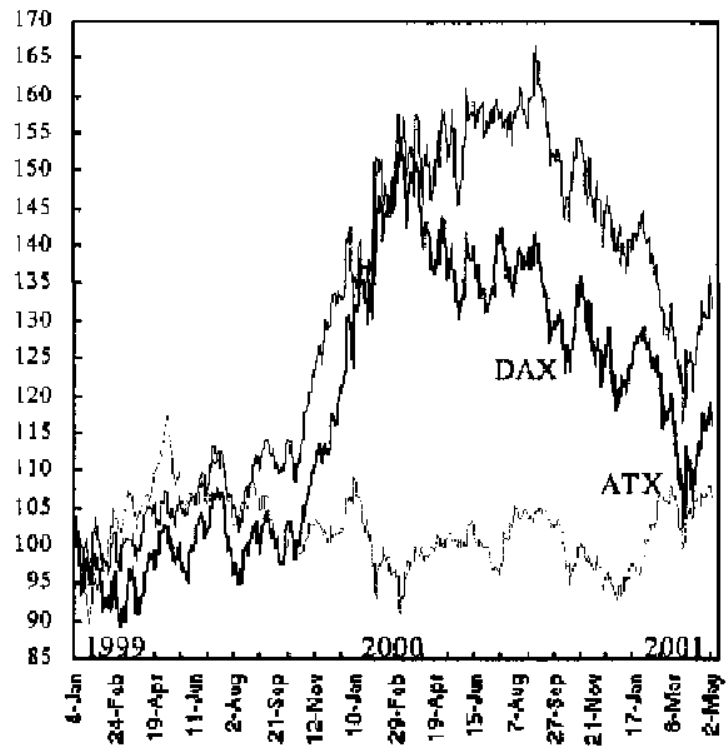

Source: Bloomberg.

Figure 8. Austria: Effective Exchange

has been depreciating throughout the $1990 \mathrm{~s}$, reflecting the lagged effects of industrial restructuring in the 1980 s, heavy investment in manufacturing, and the outsourcing of lower value added activities to the CEECs (Figure 8). The strengthening competitive position has led to improvements in the goods and services balances, with current account deficits mainly the result of a negative international investment position and net transfers to the EU (Table 1). As trade is heavily concentrated on the EU, a strengthening of the euro would not immediately depress competitiveness. However, EU enlargement could represent a challenge in the medium-term, if the existing members emulated Austria by boosting their competitiveness by outsourcing to the new members their low value added activities. Rates $(1990=100)$

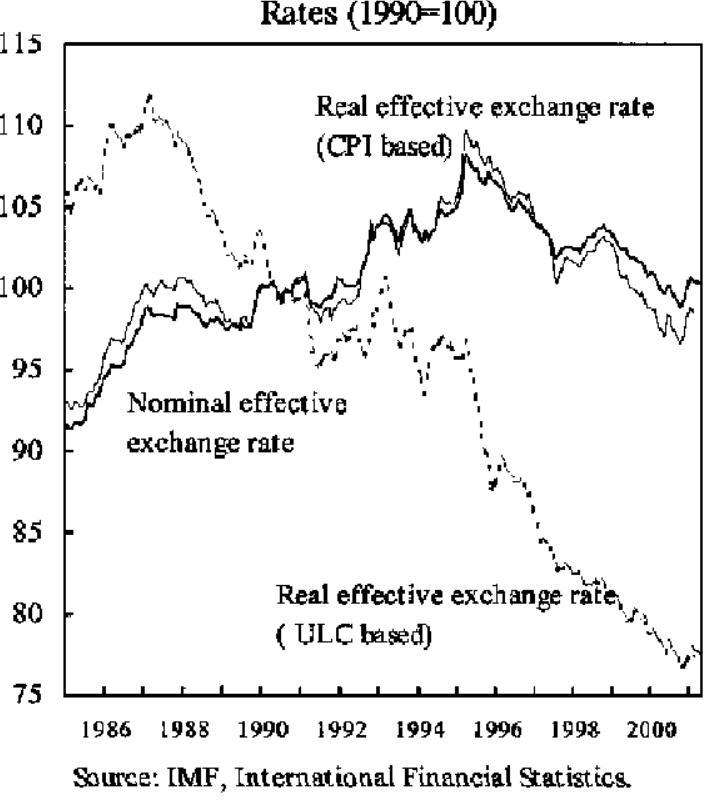


6. Economic prospects remain reasonably bright. Supported by resilient domestic demanc, growth is projected to subside to around 2.2 percent in 2001, before picking up to 2.6 percent in 2002 as the external environment improves and domestic confidence strengthens (Figure 9). Despite a tight labor market (unemployment is projected to stabilize at slightly above $31 / 2$ percent), wage pressures are expected to remain limited as continued restructuring and outsourcing help maintain wage moderation in the private sector while fiscal consolidation measures put a lid on public sector wage growth. Reflecting expected lower oil prices, headline inflation is projected to decline to around $1 \frac{13}{4}$ percent in 2001 and further to about $1 \frac{1}{2}$ percent in 2002 . The risks to this forecast, which is $1 / 2$ percent below the April Consensus Forecast for 2001 but identical with that forecast for 2002 , are broadly balanced: a sharper slowdown in Europe could dampen external demand and domestic confifdence more than envisaged, while domestic demand could strengthen over time in the event of easier monetary conditions.

Figure 9. Austria: Contribution of Demand Components to Real GDP Growth (In percent)

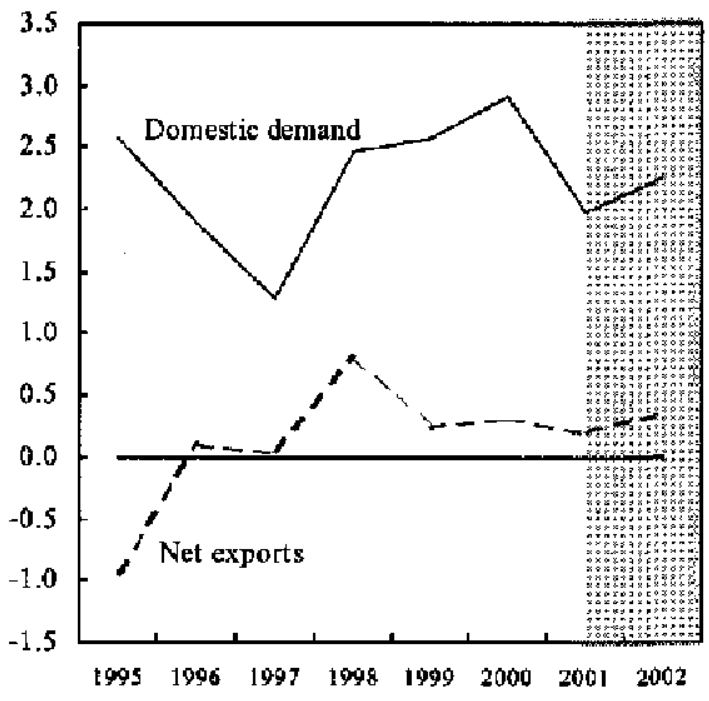

Soure: IMF, World Economic Outlook.

\section{REPORT ON THE DISCUSSIONS}

\section{The government's agenda for 2001-03 combines fiseal adjustment with} accelerated structural reforms. After a major consolidation effort in 1996-97, fiscal policy drifted for 3 years (Table 2), with general government expenditure and the budget deficit as a percent of GDP among the highest in the euro area (Figure 10). Fiscal adjustment has recently regained momentum with a revision of the authorities' 2001-04 Stability Program that targets balancing the general government budget as early as 2002 (Table 3, Box 1 and Box 1 Table). A reduction of the tax burden (partially included in the Stability Program) is planned for 2003, after having reached the "zero deficit" target. The government also places strong emphasis on speeding up privatization, liberalization of public utilities, and regulatory reform.

\footnotetext{
'The mission's forecast assumes German economic growth of less than 2 percent in 2001.
} 
Figure 10. Euro Area: Fiscal Balances (Actual and Targeted), Expenditure Ratios, and Public Debt

(In percent of GDP)
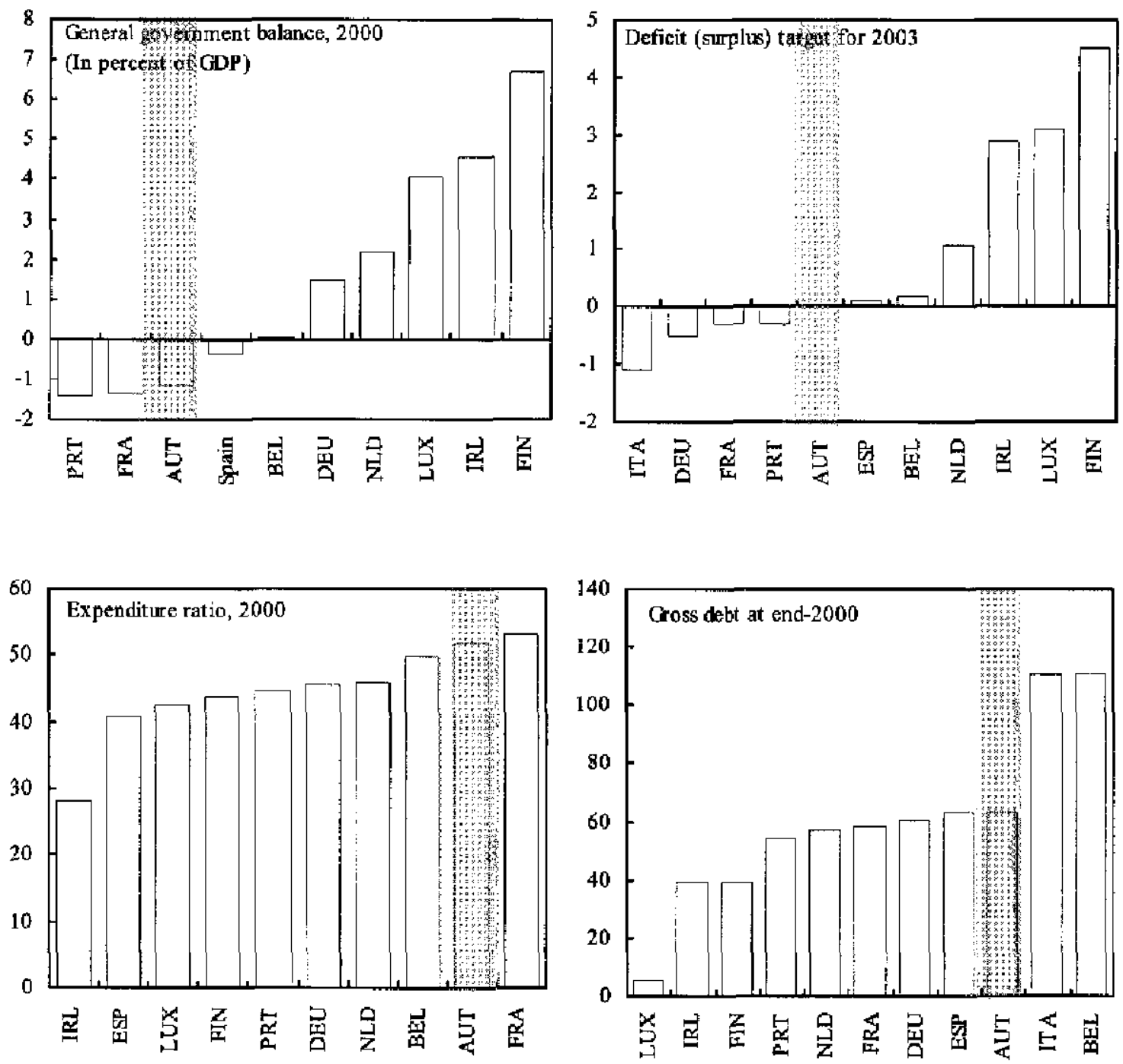

Source: IMF, World Economic Outlook 


\section{Box 1: The 2001-04 Stability Program}

Faced with strong criticism from the EU and international institutions over the unambitious March 2000 update of their Stability Program, the authorities prepared a revised Stability Program that places greater emphasis on fiscal consolidation and targets reaching general government balance by 2002 and maintaining it thereafter, a cumulative structural adjustment of about $1 \frac{1}{2}$ percent of GDP. This new deficit target has been welcomed by ECOFIN.

The 2001 federal budget represents the first step in the fiscal adjustment program and targets a federal government deficit of 1.4 percent of GDP. Savings measures by the lower levels of government would help bring the general government deficit to about $3 / 4$ percent of GDP. On balance, the Stability Program's measures (Box 1 Table) at the federal level compensate for disappearing extraordinary revenues, and the federal government budget deficit remains unchanged from 2000.

- Tax measures amount to about 1 percent of GDP and enlarge the tax base by closing loopholes and eliminating preferential treatments. The most important measures are:

- Abolition of a special tax depreciation allowance, which allowed enterprises to write off more than 100 percent of the acquisition cost of investments in productive assets. Expected yield: 0.2 percent of GDP.

- Stricter corporate tax rules as regards, inter alia, loss carry-forwards, reserves, capitalization of late payments, and depreciation rules for buildings. Expected yield: 0.5 percent of GDP.

- Increased taxation of trust funds (increase in taxation of initial deposits from 2.5 percent to 5 percent; capital income taxed at 12.5 percent instead of 0 percent; and taxation of withdrawals decreased from 25 pereent to 12.5 percent). Expected yield: less than 0.1 percent of GDP.

- Measures to broaden the wage tax base. Expected yield: 0.2 percent of GDP.

- Higher discretionary expenditures (inter alia, spending on $R \& D$, restitution payments for slave labor and confiscated property of Holocaust victims, and transfers to the railways) exceed by about 0.6 percent of GDP savings on pensions (from the higher early retirement age), public sector wages (from reducing the number of civil servants via attrition), and better targeted social expenditures.

To balance the general government budget by 2002 , a further $3 / 4$ percent of GDP adjustment is necessary. The 2002 budget (passed on April 4, 2001) envisages shrinking the federal government deficit to $3 / 4$ percent of GDP via lower expenditures (largely stemming from a reversal of the 2001 increase in discretionary expenditures). General govenment balance would be achieved by an unchanged surplus of $3 / 4$ percent of GDP at the lower government levels.

For 2003-04, maintaining the general government balance is foreseen. A planned reduction of nonwage labor costs (amounting to about $1 / 4$ percent of GDP) in 2003 is programmed to be financed by offsetting reductions in discretionary expenditures and by savings on pensions and public sector wages. Lower interest payments are expected to contribute 0.1 percent of GDP each year. 


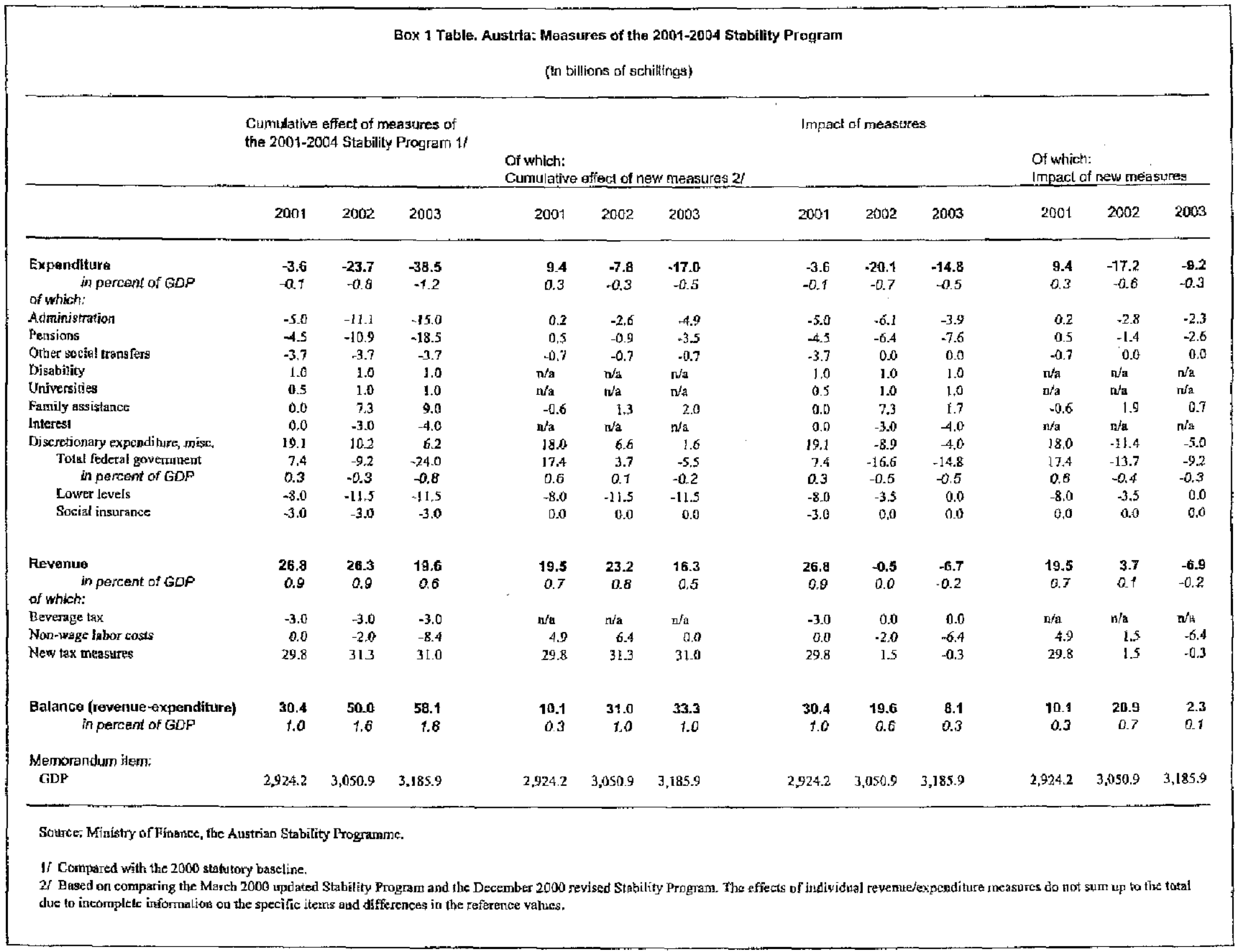

CInternational Monetary Fund. Not for Redistribution 
8. The discussions focused on the 2001-02 fiscal adjustment program and mediamterm fiscal plans. The structural and regulatory reform agenda, financial prudential issues, and the effects of EU enlargement on Austria also figured prominently in the discussions. By contrast, monetary conditions were discussed only with respect to their implications for fiscal and structural policies.

\section{A. The Short-Term Policy Stance}

9. The OeNB considered monetary conditions appropriate for Austria. Although growth was slowing, it was expected to remain solid, and there were no signs that economic activity was hampered by overly high interest rates or a lack of liquidity. However, with Austrian fiscal policy set to be slightly contractionary and inflation and credit growth below the euro area average, the Finance Ministry and the mission considered that a moderate reduction of policy rates by the European Central Bank (ECB), as eventually implemented in May 2001, was unlikely to create a policy dilemma.

10. Fiscal policy is set to be slightly contractionary in $\mathbf{2 0 0 1 - 0 2}$. The 2001 and 2002 federal budgets, together with savings at the lower levels of government, envisage a cumulative structural fiscal adjustment of about $1 \frac{1}{2}$ percent of GDP, evenly distributed over the two years. While the economy is currently running at close to capacity, the planned fiscal withdrawal coincides with a weakening of growth prospects. However, the authorities and the mission agreed that growth and employment effects of the fiscal tightening were likely to be minor, with the output gap opening up only slightly. ${ }^{2}$ The authorities were of the view that - in light of the limited real costs under current projections - strict adherence to the "zero deficit" target was needed to demonstrate their commitment to fiscal adjustment despite less favorable growth prospects. However, a more rapid slowdown in growth to below 2 percent in 2001 would cause them to reconsider their current fiscal plans. The mission agreed that credibility costs from a failed fiscal adjustment effort could be substantial, arguing that relaxing the discretionary fiscal stance by allowing non-cyclical expenditure overruns was to be avoided. However, automatic stabilizers should be allowed to operate freely, in particular if substantial downside risks to growth were to materialize.

\section{B. Fiscal Adjustment-Composition and Risks}

11. Political commitment to fiscal adjustment remains strong. The authorities rallied public support behind the "zero deficit" objective and considered that all adjustment measures were already in place to achieve general government balance by 2002 . Enough slack had been incorporated in the federal budgets for 2001 and 2002 to offset moderate cyclical shortfalls or slightly weaker fiscal performance at the lower levels. In particular,

\footnotetext{
2 The relatively small contractionary effects are based on estimates by WIFO, an Austrian research institute, and are in line with experience during the 1996-97 fiscal adjustment.
} 
expenditure overruns experienced in 2000 on certain items were not expected to recur, ${ }^{3}$ and cautious tax projections and generously budgeted discretionary expenditures provided some cushion. ${ }^{4}$

\section{The authorities emphasized that, although the adjustment program front-loaded} revenue raising measures, savings in public expenditure would dominate by 2003 . The fast-acting tax instruments in the 2001 budget (see Box 1), which also simplified the tax system and broadened its base, were necessary to jump-start the consolidation effort by offsetting the effects of the tax relief and family benefits legislated by the previous government and temporarily bigher discretionary spending (on iterns such as compensation for WWII forced labor, capital expenditures for the railways, and stepped-up R\&D spending). However, a reversal of the increase in discretionary spending as well as a lower wage bill (from reducing the number of civil servants by 15,000 through attrition and outsourcing, and from compressed growth in public sector wages) and pension expenditure assured that the adjustment effort would become predominantly expenditure based by 2003 (see Box 1 Table).

\section{The authorities considered the targeted contribution by the lower levels of} government to the fiscal consolidation effort realistic. The adjustment program envisaged sustained surpluses of $3 / 4$ percent of GDP by the provinces ( $L a$ ander) and balanced budgets by the municipalities for the 2001-04 period. This would require an adjustment effort of about 0.4 percent of GDP that would be achieved by expenditure reclassification (in particular, changing housing support from expenditure-increasing subsidies to highly concessional loans), cuts in administration costs, savings on teachers' salaries, compression of investment spending, and interest savings (from selling housing loans and using the proceeds to retire debt). The reclassification of expenditure was considered crucial for delivering on the provinces' fiscal targets. The authorities were confident that sanctions - still to be negotiated in conjunction with the new revenue sharing agreement (Finanzausgleich)-would have enough teeth to induce the Länder and municipalities to achieve their targeted surpluses (Box 2).

\footnotetext{
${ }^{3}$ The authorities attributed expenditure overruns in 2000 to one-off factors, such as delayed implementation of reforms in health insurance, higher-than-expected pension payments as more people took advantage of early retirement before higher age limits entered into force, higher transfers to the railways, and expenditure brought forward by the lower levels of government to facilitate achieving the targeted surpluses in 2001. At the general government level, these overruns were offset by windfalls from lower interest payments and higher-thanbudgeted proceeds from UMTS and other asset sales (negative expenditure items), so that overall expenditure remained on target.

${ }^{4}$ For instance, the R\&D spending budgeted for 2001 (about $1 / 4$ percent of GDP) could be spent over a longer period.
} 


\section{Box 2: Coordination of Public Finances}

The legal basis for coordinating public finances between the three levels of government in Austria (federal, provincial, and municipal) is provided by the revenue-sharing agreement law (Finanzausgleichsgesetz (FAG)). A formal coordination is necessary since most revenues stem from taxes levied by the federal government, but a large part of public expenditure is made at the lower levels of government.

General agreement on a new FAG that covers the period 2001-04 was reached in October 2000. Federal revenues are distributed among the provinces (Länder) and municipalities based on the size of their population, with an adjustment in favor of some Länder in the eastern and southern parts of Austria (with per capita income below the national average) and smaller municipalities. While the new FAG is already in effect, it has not yet been signed by the Länder, since the supplementary agreement specifying the lower levels' contribution to the fiscal consolidation and penalties for nonobservance is still under negotiation. In accordance with the new FAG, the Ministry of Finance has the option to withhold 0.8 percent of GDP in shared revenue if the agreement is not signed by end-2001. Penalties under the agreement would amount to a yet to be determined percentage of the fiscal underperformance.

The authorities' 2001-04 Stabilization Program relies on surpluses of at least 3/4 percent of GDP by the lower levels of government to reach and maintain the fiscal objective of a balanced general government budget. The Länder are expected to present an aggregate surplus of $3 / 4$ percent of GDP, while municipalities are assumed to have balanced budgets over the entire period. The fiscal consolidation effort expected by the Lander is significant, as it represents 10 percent of their aggregate spending. While expenditure reclassification (most of which has not yet been approved by Eurostat) will account for most of the deficit reduction, fiscal adjustment will include the elimination of earmarking federal transfers for housing subsidies, cuts in administrative costs and teachers' salaries, and a reduction in investment spending.

Agreement on some aspects of the application of sanctions under the new FAG is still pending. The remaining questions include: (1) who has the power to decide on the application of penalties (the federal government or an independent council); (2) whether and to what extent shortfalls in one year can be made up by subsequent overperformance without incurring penalties; (3) whether the sanctions should be applied only with a lag of one year following non-compliance; and (4) whether the penalties should amount to 100 percent of fiscal underperformance or less. 


\section{The mission raised concerns regarding the sustainability of the fiscal}

adjustment. Reliance on compressing expenditure within existing structures entailed the risk of creating spending pressures in subsequent years; for instance, delayed investment projects or lagging public sector wages could lead to catch-up demands. In addition, while the 2001-02 budgets appeared to have been drawn up conservatively, uncertainties existed as to the overall cost of the planned further enhancement of family benefits (Kindergeld). ${ }^{5}$ On the revenue side, calls for decreasing taxes were already intensifying (see below). Thus, risks could emerge of a return to the "stop-go" pattern of fiscal policy. The envisaged fiscal consolidation by the lower levels of government was also fraught with uncertainties, as their contribution to deficit reduction relied to a large extent on expenditure reclassification (which could be disallowed by Eurostat) and negotiations on the planned sanction mechanism had not yet been concluded. Finally, the Stability Program's target of year-toyear balance after 2002 would require adopting procyclical measures.

\section{Medium- and Long-Term Fiscal Issues}

\section{The authorities plan to reduce the revenue burden in 2003, although the extent} of the relief is yet to be determined. Priority was attached to reducing non-wage labor costs and corporate taxes (from 34 to 31 percent), the latter in response to the recent German tax reform. Cuts in income and wage taxes were considered less crucial. While the Stability Program had already included a $1 / 4$ percent of GDP reduction in non-wage labor costs (programmed to be offset by lower expenditure on pensions and public sector wages), it did not provision for further tax cuts. The mission welcomed the intended tax relief and the authorities' focus on reducing non-wage labor costs, but cautioned that in order to avoid backtracking on the fiscal adjustment effort and preserve overall fiscal balance, revenue cuts should not exceed the margin provided by expenditure restraint. The authorities replied that they would proceed with care in identifying the scope for affordable tax relief.

\section{The authorities realized that further reforms of the public finances were needed} beyond their current plans to make room for a bolder reduction in the tax burden and ensure a healthy fiscal position over the longer run. The planned 2001-02 adjustment largely exhausts the possibilities for expenditure restraint within existing structures but still leaves the size of government at over one half of GDP, nearly 5 percentage points above the EU average. The authorities intend to continue rationalization in the public sector. Their plans include further expenditure cuts at the federal level, eliminating overlaps across ministries and between federal, regional, and local government activities, and streamlining operations in the tax and customs administrations. The mission noted that additional savings could be achieved by adopting the recommendations of the administrative reform commission (including the closure of certain government offices and agencies, the transfer of

\footnotetext{
${ }^{5}$ Family benefits in Austria-most of it non-means-tested cash benefits-are one of the most generous in the EU (amounting to 2.8 percent of GDP in 1998). Planned changes include extending entitlement to, and duration of, parental allowances.
} 
indirect federal administration to the Länder, and an overhaul of the system of intergovernmental transfers). The mission stressed that farther-reaching reforms based on rethinking the desired role of the public sector and scrutinizing the efficiency of current spending programs were preferable to continued piecemeal adjustments. The former could improve economic efficiency and yield more sizable and durable expenditure reductions. Sufficiently large expenditure reductions would ensure achieving structural budget objectives, while leaving room for countercyclical policies; provide leeway for tax relief; and help prepare for the fiscal consequences of population aging.

\section{The mission argued that further reforms of the pension system were required to} ensure its sustainability and overall fiscal balance over the longer run. Austria has one of the most expensive public pension systems in Europe, currently absorbing about $14 \frac{1}{2}$ percent of GDP. The system is underfunded, with a primary deficit of about 5 percent of GDP, and recent reforms ${ }^{6}$ do not deliver long-term sustainability: the authorities project that the primary deficit of the pension system will rise by close to 1 percent of GDP by 2010 , and by a further 3 percent of GDP by $2030{ }^{7}$ Against this background, comprehensive reforms are required to decrease future liabilities and increase revenue. Measures such as lower replacement rates for new retirees, less generous indexation of existing pensions, and harmonization of civil service pensions with the general pension system would reduce liabilities. Measures to increase participation rates for older workers (raising the retirement age in line with increased longevity, accelerating the implementation of the already legislated equalization of retirement ages for men and women, eliminating the remaining incentives for early retirement, and perhaps

Figure 11. Cross Country Comparison of Labor Force Participation Rate, 55-64

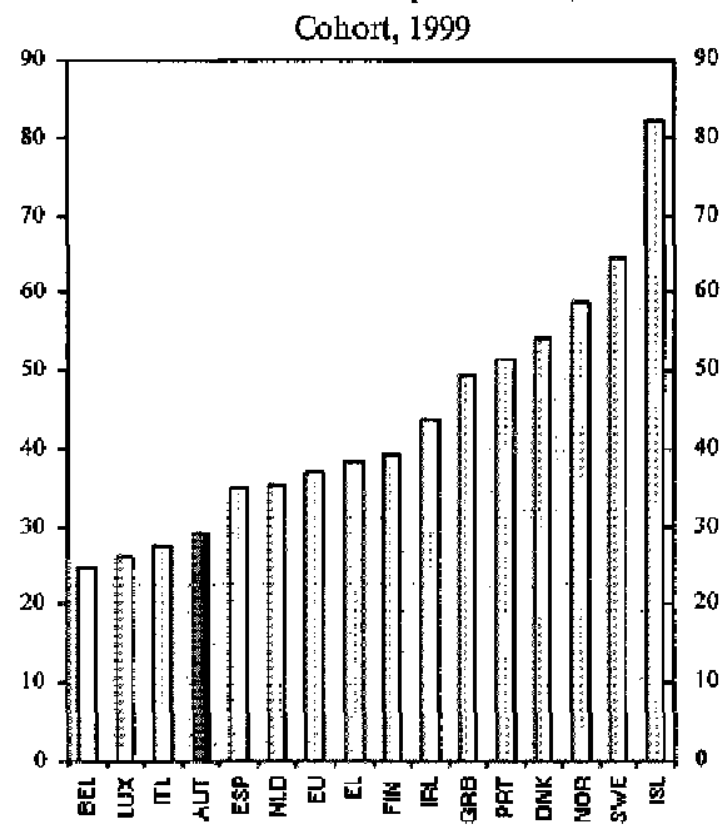

Source: Eurostat. introducing a bonus/malus system that rewards late and penalizes early retirement) would also raise the number of contributors. To raise the labor force participation rate of older workers from its current low rate (Figure 11), pension reform could be supplemented by

\footnotetext{
${ }^{6}$ These included a $1 \frac{1}{2}$-year increase in the early retirement age, larger discounts for early retirement, and an increased retirement age for women from 60 to 65 to be phased in during 2019-2034.
}

${ }^{7}$ Staff projections are more pessimistic over the longer run. 
targeted active labor market policies (ALMPs). ${ }^{8}$ While the authorities concurred that under current policies the fiscal stress generated by the pension system over the longer run would be considerable, no consensus existed within the government to implement changes during the current legislative period.

\section{Structural Issues}

18. The first phase of the government's privatization program is on track; however, implementation of the second phase is on hold. The state still maintains effective control of several key industrial companies and utilities, and many savings banks are controlled by the local authorities. The government plans to sell all remaining industrial equity holdings and to deregulate public utilities (electricity, gas, telecom and transportation). The first phase of the privatization program has proceeded on schedule, and federal government shares in the P.S.K. bank, Vienna Airport, and Telekom Austria were sold in 2000 and early 2001, in the latter case partially. The sales of holdings in Austria Tabak, the Dorotheum auction house, and the State Printing Press by end-2001 are expected to complete the first phase. In the second phase, flagship enterprises in the steel, engineering, and oil industries as well as Austrian Airlines and the postal services are to be privatized. However, gathering momentum to launch this phase proved to be difficult. Timing and methods were still debated and the authorities thought that the current stock market and business climate (especially in the airlines and telecoms industries) justified postponing further privatization.

\section{Progress with structural and regulatory reform in product markets has been}

uneven. The liberalization of network industries was proceeding on schedule, with telecommunications furthest ahead, and the full opening of the electricity and gas sectors envisaged by October 2001 and October 2002 respectively, well ahead of EU deadlines. Experience with deregulation was positive, as stronger competition had led to lower prices in telecoms and the already liberalized segment of the electricity market (Figure 12). The authorities planned to finalize their proposal for an independent competition authority by the end of 2001 . The new authority could initiate investigations at its own discretion, but decisions would be left in the purview of the Cartel Court. Progress with other initiatives has proceeded at a measured pace. The government's proposal to extend weekly shopping hours from 66 to 72 and liberalize daily opening hours was yet to be legislated. Proposals to streamline the administrative requirements for approving business licenses and investment projects by introducing a time-bound "one-stop-shop" procedure and to reduce the number of trades and professions subject to licensing requirements were, after three years, still in the preparatory phase.

\footnotetext{
${ }^{8}$ The recent EU decision at the Stockbolm Summit targets a 50 percent participation rate for the pre-retirement cohort by 2010, compared with Austria's current 29 percent.
} 
Figure 12. Cross Country Comparisen of Prices
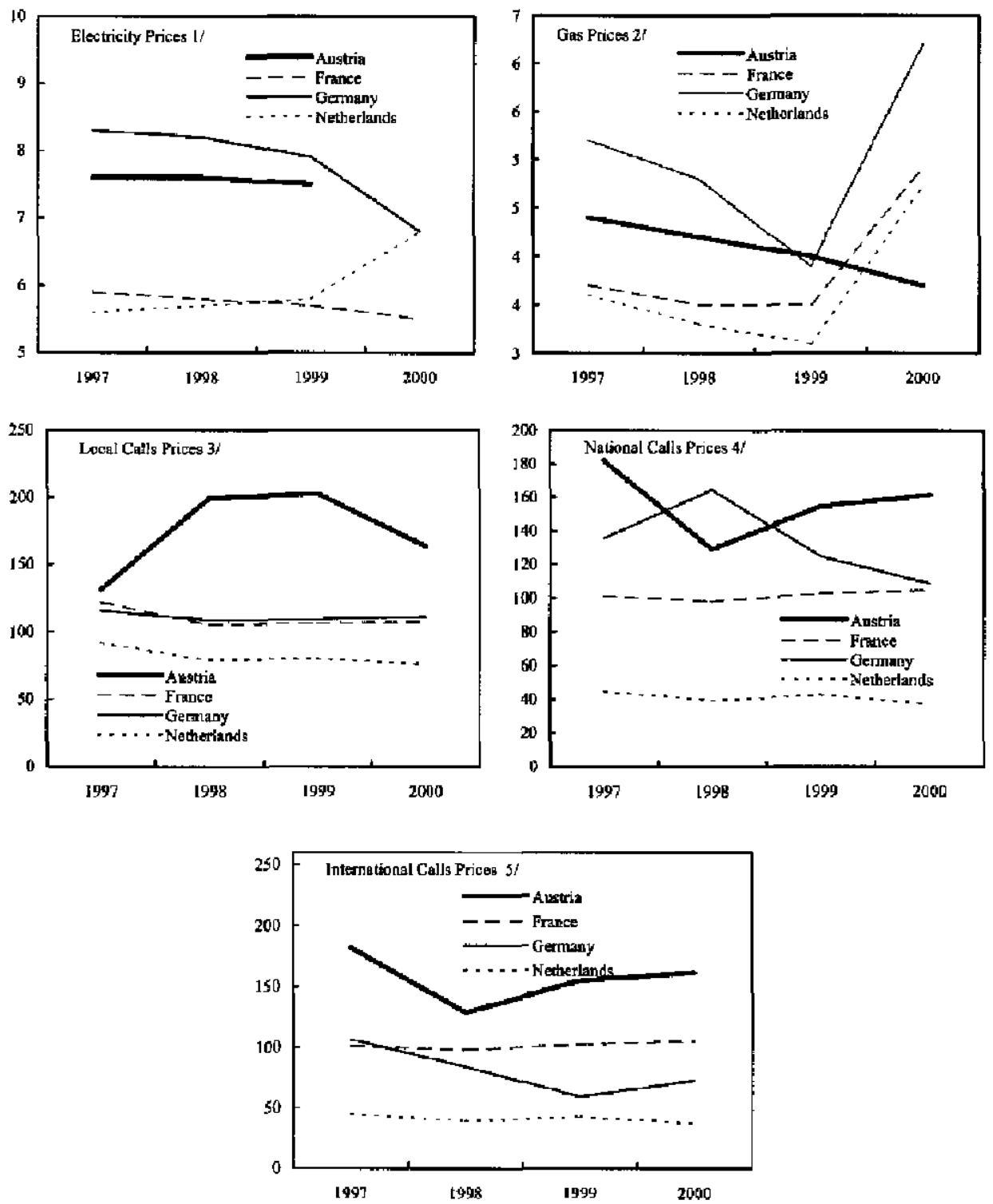

Source: Eurostat for energy statistics; DG INFSO for telecommunications data. 1/ Price in euro per $100 \mathrm{kWh}$ for industry.

2/ Price in euro per gipgioule for industry.

3/ Price in euro of 10 minute call at 11 am on a weekday (including VAT) for local call ( $3 \mathrm{~km}$ ) relative to EU=100.

4/ Price in euro of 10 minute call at 11 am on a weekday (including VAT) for national call (200km) relative to $\mathrm{EU}=100$.

5/ Price in euro of 10 minute call at 1.1 am on weekday (including VAT) for international call (to USA) relative to EU=100, 


\section{Labor market performance is good, but raising participation rates remains a} challenge. The positive features of Austria's labor market performance include aggregate wage moderation, unemployment below 33/4 percent, low long-term and youth unemployment ${ }^{9}$, and near-achievement of the National Action Plan's targets. ${ }^{10}$ However, labor force participation of older workers remains low. The authorities agreed that in light of demographic trends, steps to stimulate labor supply were necessary to ease impediments to growth and pressure on public finances, and identified reversing the trend towards early retirement and encouraging female labor supply as priority areas. In the mission's view, removing labor supply disincentives for these groups (e.g., througb pension reform and restructuring family support from cash payment to the provision of affordable child-care facilities) would be the most promising policy instrument. Policies to ease labor market rigidities and stimulate job creation as well as targeted ALMPs could help accommodate the higher labor supply without undue friction.

21. Austria stands to benefit from EU enlargement. The authorities noted that Austria has been a net beneficiary from closer ties with its CEEC neighbors" and stands to gain when these countries fully join the EU, on account of single market effects (economies of scale and lower markups from increased price competition), a further increase in trade, and the easing of some labor shortages and the fiscal consequences of population aging through immigration. ${ }^{12}$ However, political acceptance of enlargement was somewhat lagging behind already advanced economic integration. Labor markets and trade in services involving the movement of labor were particular concerns. While no major immigration flows were expected after enlargement, the long border with accession countries meant that a potentially large number of commuters could generate significant stress in certain regions and labor market segments (e.g., at the low-skilled end of the market). In the authorities' view, a

\footnotetext{
${ }^{9}$ This can be partly attributed to responsible behavior by the social partners, ALMPs with special emphasis on enhancing the employability of vulnerable groups via education, training, coaching and employment promotion schemes, and apprenticeship training (SM/00/179).
}

${ }^{10}$ Austria's 1998 National Action Plan aimed at creating 100,000 new jobs, reducing unemployment to 3.5 percent, and increasing the share of the unemployed in ALMPs to 20 percent by 2002 . The employment objective was met two years ahead of schedule, and the latter two targets are close to being achieved.

${ }^{11}$ WIFO estimates that increased exports to CEECs (Hungary is now Austria's third largest trading partner) have created 40,000 jobs in manufacturing in net terms. Outsourcing in manufacturing and services is thought to be a factor in keeping inflation one of the lowest in the EU, benefiting Austrian consumers.

${ }^{12}$ A study by WIFO estimates a cumulated net enlargement effect of about ${ }^{3 / 4}$ percent of GDP in the 5 years following enlargement. 
flexible seven-year transition period for the free movement of labor would help assuage widespread fears of mass migration and commuting as well as smooth smaller absorption problems. In the event, the European Commission's proposal has been formulated along similar lines. As an EU proposal temporarily restricting the flow of services involving the movement of labor was not expected, Austria had to rely on structural reforms to strengthen the competitiveness of the service activities likely to be affected.

\section{E. Financial Sector Issues}

22. The authorities considered the Austrian banking system fundamentally sound, partly as a result of the successful implementation of internationalization strategies in the sector. Banks appeared sufficiently capitalized (Table 4) and their risk management strategies were considered adequate. Although trends toward cost cutting and consolidation among the smaller banks due to competitive pressures continued, profitability was satisfactory, with the return on equity as high as 30 percent for some banks' activities in CEEC markets. The challenges from changing consumer savings behavior and globalization had not given rise to major problems: banks made up for the decline in their deposit base by medium- and long-term bond issues, and the internationalization of the banking sector had strengthened further with the merger of Bank Austria (the largest Austrian bank) and the German HypoVereinsbank and the continued expansion of Austrian banks to CEEC markets. In the authorities' assessment, no particular vulnerabilities were visible: the share of nonperforming loans was low and the growth in foreign currency lending to private nonbanks had slowed. ${ }^{13}$ Although the authorities acknowledged the risks from the Austrian banks' increasing involvement in CEEC markets, they considered the banks' eastward expansion strategy - which exploited knowledge of the local markets and concentrated on the upper segments of the corporate and consumer credit market-sufficiently prudent. To improve the supervision of foreign subsidiaries, memoranda of understanding were being negotiated with CEEC supervisors to facilitate the exchange of information and allow on-site inspections by Austrian supervisors. ${ }^{14}$ The authorities thought that after a new supervisory framework had been put into place (see below), participation in an FSAP could be useful to identify any stress points and vulnerabilities in the financial sector.

\footnotetext{
${ }^{13}$ Nonperforming loans (NLPs) amounted to 3 percent of total loans at end-1999 and provisions for these loans were equivalent to about 5 percent of GDP ( $781 / 2$ percent of NPLs). The share of foreign currency loans (mostly denominated in Swiss francs and yen) in total loans extended to private households and companies increased from 15.7 percent in December 1999 to 17.5 percent in February 2001. This rise was attributed mainly to valuation effects. Banks accounted for the higher risk of these loans by a higher collateral margin.
}

${ }^{14}$ A memorandum of understanding with Slovenia had been concluded, while discussions were in progress with the Czech Republic, Hungary and Slovakia. 
23. The authorities and the mission agreed that the planned reform of financial supervision should aim at strengthening regulatory capacity. Adequate resources and operational independence were recognized as necessary conditions for effective supervision. Especially with a view to the growing number of Austrian banks' subsidiaries in CEECs and planned on-site inspections in these countries, banking supervision would most likely require additional staff to maintain its effectiveness. Views, however, differed as to the desirable institutional structure of supervision. The Ministry of Finance favored integrating supervision of financial markets in a new agency to eliminate the current institutional fragmentation of supervision and to anticipate financial market trends towards the formation of conglomerates. ${ }^{15}$ By contrast, officials of the OeNB thought that the present structure of financial markets (strongly segmented with no conglomerates) would not be well served by integrated supervision. The mission emphasized that ensuring sufficient authority, adequate instruments and full independence of the supervisor should take priority over the institutional setup. In particular, seeking political consensus on the institutional structure should not jeopardize the quality of supervision. ${ }^{16}$ The draft legislation submitted to parliament after the conclusion of the mission envisages integrated supervision of banking, securities, insurance companies and pension funds by a new, fully independent agency from April 1, 2002, with 90 percent of the costs covered by the private sector.

24. The authorities considered the new capital market law (Kapitalmarktoffensivgesetz, or KMOG) a useful step to improve the functioning of the capital market. While acknowledging the mission's concerns that the new law's tax provisions discriminated between Austrian and foreign mutual funds and between equity and bond financing, the autborities stressed that the KMOG had reduced distortions in the capital market by abolishing the general tax on all capital market transactions.

\section{STAFF APPRAISAL}

25. The Austrian economy performed well in 2000: strong growth was accompanied by falling unemployment and low inflation. Although there are no acute economic problems and the outlook is favorable, longer-term policy challenges remain. The recent fiscal policy correction and steps to liberalize utilities are welcome, but a large public sector with a high tax burden, an underfunded social security system, and a heavily regulated economy cloud the horizon.

26. The authorities' 2001-04 Stability Program has given new momentum to fiscal consolidation. Against the background of persistent government deficits, high public debt,

${ }^{15}$ Currently, supervisory responsibilities are shared by the Ministry of Finance, the Austrian National Bank, and the Securities Supervision Agency.

${ }^{16}$ The proposed reform requires constitutional changes, and thus a two-thirds majority in parliament. 
and one of the highest expenditure ratios in the EU, the plan to reach general government balance by 2002 is an important step toward sound public finances. The government is to be commended for recognizing the need for fiscal adjustment and acting decisively to popularize the concept of a "zero deficit" and obtaining parliamentary approval for the 2001 and 2002 federal budgets that are consistent with this objective. It is now important to conclude the agreement on the contribution of the lower levels of government to the adjustment and to ensure that consolidation at the lower levels represents genuine fiscal reforms and avoids recourse to expenditure reclassification.

\section{Although the authorities' fiscal plans are commendable, some concerns remain} as to the sustainability of the proposed consolidation. First, the lack of structural fiscal reforms implies that pressures are likely to build on both the expenditure and the revenue side, risking future fiscal backsliding. Second, the deficit reduction relies heavily on surpluses by the lower government levels. Lack of cooperation by the lower levels and changes in expenditure classification rules could frustrate reaching the balanced budget objective. Third, strict adherence to a "zero deficit" on a year-to-year basis would likely require procyclical measures and adoption of a structural fiscal balance target would be preferable instead.

\section{With the 2001 and 2002 budgets a fait accompli, the fiscal policy debate should} adopt a longer-term focus. International competition will sharpen the need to narrow the scope of the public sector's direct economic involvement, and pressures to reduce the tax burden are unlikely to abate. The absence of regional or national elections until some time in 2003 and the wealth of technical and factual information already at the disposal of the authorities offer the opportunity to proceed with the adoption of a comprehensive civil service and administrative reform, with a view to permanently shrinking the size of government.

29. Pension reform should figure prominently in fiscal plans. Without changes to the current system, population aging is putting public finances on an unsustainable trajectory. Temporary fiscal surpluses, while mitigating the problem, are no substitute for comprehensive pension reform. Delaying such reform will ultimately require more painful adjustment, and the demographic window of opportunity will close around 2010. A balanced long-term fiscal position, therefore, needs to encompass pension reform, and the authorities are urged to formulate their plans and implement reform measures.

\section{Challenges from a rapidly integrating Europe should provide a powerful} incentive to implement the authorities' unfinished structural agenda. Although agreement on such reforms is often difficult in a consensus-based federal system, removal of regulatory and other impediments to competition and flexibility in the product, capital and labor markets is crucial in the absence of an independent monetary policy to deal with increasing competition from abroad, including from future EU enlargement. Thus, the authorities are encouraged to complete the final phase of their privatization program and not to delay launching its second phase; pursue liberalization and regulatory reform in the product markets more vigorously and shorten legislative and implementation lags for 
initiatives already in the pipeline; and stimulate labor supply and ease rigidities in the labor market to prepare for the consequences of population aging.

\section{The planned reform of financial supervision should focus on strengthening its}

effectiveness. Full independence of supervision should not be compromised, and the changeover to the proposed new arrangement will need to be carefully managed so as not to weaken regulatory capacity in the transition process. If supervisory independence cannot be secured at this stage, it would be better to strengthen supervising capacity within the present structure. Although the authorities view the banking system as healthy, supervisors should remain vigilant, especially in light of the growing activity of Austrian banks in the CEECs.

\section{Austria should strengthen its efforts to alleviate world poverty and stimulate} international trade. Within its overall fiscal objectives, Austria should reverse the decline (to a projected 0.21 percent of GNP in 2001) in its official development assistance and raise it toward the international benchmark of 0.7 percent of GNP. Austria should use its influence in the EU to speed up the phase-out of remaining import restrictions affecting the least developed countries and extend the EU's import concessions to these countries to all developing countries, promote agricultural reform in the $\mathrm{EU}$, and liberalize world trade in agricultural products and services under the auspices of the WTO.

33. Although generally adequate for surveillance, the timeliness of Austria's data on national accounts, industrial production, the external trade and the current account should be improved.

34. The Article IV consultation with Austria is proposed to be kept on the standard 12-month cycle. 


\begin{tabular}{|c|c|c|c|c|c|c|c|c|c|c|c|}
\hline & 1996 & 1997 & 1998 & 1999 & 2000 & 2001 & 2002 & 2003 & 2004 & 2005 & 2006 \\
\hline & \multicolumn{11}{|c|}{ (In biltions of schillings) } \\
\hline Current account batance & -57.5 & -79.2 & -64.5 & -85.4 & -80.9 & -79.8 & -67.1 & $-56,6$ & -54.4 & -52.2 & -45.6 \\
\hline (In percent of GDP) & -2.3 & -3.2 & -2.5 & -3.2 & -2.9 & -2.7 & -2.2 & $-J .8$ & -1.6 & -1.5 & -1.3 \\
\hline Goods and services balance & -28.9 & 39.9 & -16.1 & -23.7 & -28.1 & -16.7 & -1.1 & 10.8 & 16.3 & 25.4 & 36.1 \\
\hline Trade balance & -77.0 & -52.0 & -45.3 & -46.5 & -39.7 & -33.5 & -28.5 & -28.8 & -31.3 & -31.1 & -30.3 \\
\hline Expotts & 613.9 & 716.1 & 776.3 & 832.6 & 958.4 & $1,030.2$ & $1,105.6$ & $1,181.6$ & $1,260.3$ & $1,343.5$ & $1,431.3$ \\
\hline Imports & 690.9 & 768.0 & 821.5 & 879.0 & 998.1 & $1,063.7$ & $1,134,2$ & $1,210.4$ & $1,291.6$ & $1,374.6$ & $1,461.6$ \\
\hline Tourism balance & 18.6 & 10.8 & 20.7 & 23.8 & 20.9 & 24.5 & 30.9 & 38.2 & 44.4 & 51.3 & 59.0 \\
\hline Receipts & 135.3 & 134.1 & 138.4 & 142.5 & 147.6 & 158.9 & 173.5 & 189.5 & 204.9 & 221.6 & 239.7 \\
\hline Expenditures & 116.7 & 123.2 & 117.7 & 118.7 & 126.7 & 134.4 & 142.6 & 151.3 & 160.5 & 170.3 & 180.7 \\
\hline Other services, net & 29.5 & 1.2 & 8.5 & -1.1 & -9.3 & -7.7 & -3.4 & 1.4 & 3.2 & 5.2 & 7.4 \\
\hline Net factor income & -9.8 & -18.6 & -24.5 & -35.5 & -32.6 & -39.1 & -42.0 & -43.3 & -46.7 & -53.5 & -57.7 \\
\hline Transfers balance & -18.8 & -20.7 & -23.9 & -26.2 & -20.2 & -24.0 & -24.0 & -24.0 & -24.0 & -24.0 & -24.0 \\
\hline Capital account & -1.0 & -1.5 & -4.2 & -3.4 & -6.7 & -6.7 & -6.7 & -6.7 & -6.7 & -6.7 & -6.7 \\
\hline Financial account & 52.5 & 75.0 & 76.1 & 89.3 & 70.7 & 86.5 & 73.8 & 63.2 & 61.1 & 58.8 & 52.2 \\
\hline Net foreign direct investment & 26.4 & 8.1 & 22.1 & -0.7 & 89.0 & 10.0 & 10.0 & 10.0 & 10.0 & 10.0 & 10,0 \\
\hline Net portfolio investment & -22.4 & 18.9 & 81.2 & -40.5 & 14.5 & 14.5 & 14.5 & 14.5 & 14.5 & 14.5 & 14.5 \\
\hline Net other investment & 55.3 & 0.6 & 10.2 & 109.2 & -38.7 & 62.0 & 49.2 & 38.7 & 36.5 & 34.3 & 27.7 \\
\hline Financial derivatives & 4.3 & 11.4 & 2.7 & -5.7 & -5.7 & 0.0 & 0.0 & 0.0 & 0.0 & 0.0 & 0.0 \\
\hline Change in reserves & -11.1 & 35.9 & -40.1 & 27.0 & 11.5 & 0.0 & 0.0 & 0.0 & 0.0 & 0.0 & 0.0 \\
\hline
\end{tabular}

Sources: Austrian National Bank; and IMF staff projections. 
Table 2. Austria: General Government Finances--National Accounts Basis 1/

\begin{tabular}{|c|c|c|c|c|c|c|}
\hline & 1996 & 1997 & 1998 & 1999 & $20002 /$ & $20013 /$ \\
\hline & \multicolumn{6}{|c|}{ (In billions of schillings) } \\
\hline Revenue & $1,293.0$ & $1,309.7$ & $1,357.5$ & $1,397.6$ & $1,436.4$ & $1,496.6$ \\
\hline (In percent of $G D P$ ) & 52.8 & 52.1 & 51.9 & 51.5 & 50.7 & 51.2 \\
\hline Production and import taxes & 355.2 & 376.6 & 391.4 & 408.1 & 419.2 & 438.2 \\
\hline Income and wealth taxes & 321.2 & 339.5 & 358.2 & 363.4 & 373.0 & 416.2 \\
\hline Property income & 37.5 & 33.8 & 28.9 & 28.7 & 28.1 & 26.5 \\
\hline Social contributions & 427.6 & 435.9 & 451,0 & 464.1 & 481.8 & 495.2 \\
\hline Other revenue & 151.6 & 123.9 & 128.1 & 133.2 & 134.2 & 120.5 \\
\hline Expenditure & $1,386.7$ & $1,353.5$ & $1,417.5$ & $1,455.0$ & $1,468.8$ & $1,518.3$ \\
\hline (In percent of GDP) & 56.6 & 53.8 & 54.2 & 53.6 & 51.8 & 51.9 \\
\hline Current expenditure & $1,268.3$ & $1,253.2$ & $1,305.6$ & $1,351.1$ & $1,385.3$ & $1,414.4$ \\
\hline Compensation of employees & 302.3 & 288.2 & 296.7 & 310.2 & 318.7 & 324.5 \\
\hline Goods and services & 158.9 & 139.2 & 148.9 & 156.7 & 162.3 & 166.1 \\
\hline Subsidies & 64.4 & 64.4 & 72.5 & 71.5 & 71.0 & 79.7 \\
\hline Interest payments & 103.8 & 97.4 & 98.5 & 97.0 & 94.3 & 96.9 \\
\hline Social transfers & 522.6 & 545.3 & 539.6 & 558.0 & 578.0 & 655.8 \\
\hline Other current expenditure & 116.3 & 118.7 & 149.4 & 157.7 & 161.0 & 91.5 \\
\hline Capital expenditure & 118.4 & 100.2 & 111.9 & 103.9 & 83.5 & 103.8 \\
\hline Gross fixed capital formation & 69.4 & 49.4 & 48.5 & 50.2 & 47.5 & 49.5 \\
\hline Property purchase & 0.1 & -1.6 & -0.4 & -0.2 & -18.8 & -2.2 \\
\hline Capital transfers & 48.9 & 52.5 & 63.7 & 54.0 & 54.8 & 56.5 \\
\hline Financial balance & -93.7 & -43.8 & -60.0 & -57.4 & -32.4 & -21.7 \\
\hline (In percent of GDP) & -3.8 & -1.7 & -2.3 & -2.1 & -1.1 & -0.7 \\
\hline \multicolumn{7}{|l|}{ Memorandum item: } \\
\hline Nominal GDP & $2,450.0$ & $2,513.5$ & $2,614.7$ & $2,712.0$ & $2,833.9$ & $2,924.2$ \\
\hline
\end{tabular}

Sources: Austrian Statistical Office; Ministry of Finance; and DMF staff projections.

1/ Based on ESA95.

2/ Preliminary estimates, Ministry of Finance.

3/ 2001 budget. 
Table 3. Austria: Fiscal Projections Based on the 2001-2004 Stability Program

\begin{tabular}{|c|c|c|c|c|c|c|c|c|c|c|}
\hline & 1995 & 1996 & 1597 & 1998 & 1999 & 2000 & 2001 & 2002 & 2003 & 2004 \\
\hline & \multicolumn{10}{|c|}{ (In percent of GDP) } \\
\hline Revernue & 32.1 & 52.8 & 52.1 & 51.9 & 51.5 & 50.7 & 51.2 & 50.5 & 50.3 & 50.2 \\
\hline Expenditure & 57.2 & 56.6 & 53.8 & 54.2 & 53.6 & 51.8 & 51.9 & 50.5 & 50.3 & 50.2 \\
\hline Overall fiscal balance $\mathrm{t} /$ & -5.1 & -3.8 & -1.7 & -2.3 & -2.1 & -1.1 & -0.7 & 0.0 & 0.0 & 0.0 \\
\hline Federal government & $=4.7$ & .40 & .2 .7 & -2.9 & -2.4 & -1.4 & -1.4 & -0.7 & -0.7 & -0.7 \\
\hline Other levelg & -0.5 & 0.2 & 1.0 & 0.6 & 0.3 & 0.3 & 0.7 & 0.7 & 0.7 & 0.7 \\
\hline \multicolumn{11}{|c|}{ minus onz-off measures and net lending } \\
\hline Net subsidized Ieriding $2 f$ & 0.7 & 0.7 & 0.4 & 0.3 & 0.4 & 0.4 & 0.4 & 0.4 & 0.3 & 0.3 \\
\hline Net sale of real estate $3 /$ & -0.2 & 0.0 & 0.1 & 0.0 & 0.0 & 0.1 & 0.2 & 0.2 & 0.2 & 0.2 \\
\hline Sale of UMTS licences & 0.0 & 0.3 & 0.4 & 0.0 & 0.1 & 0.4 & $0 . \mathrm{I}$ & 0.1 & 0.0 & 0.0 \\
\hline \multicolumn{11}{|l|}{ pitus } \\
\hline Cyclical adjustment & 0.3 & 0.4 & 0.8 & 0.4 & 0.3 & 0.0 & 0.2 & 0.2 & 0.1 & 0.1 \\
\hline Structural balance & -5.4 & -4.5 & -19 & -2.3 & -2.2 & -2.0 & -1.2 & -0.5 & -0.5 & -0.4 \\
\hline \multicolumn{11}{|l|}{ plust } \\
\hline Net interest payments & 3.4 & 3.2 & 2.9 & 2.8 & 2.6 & 2.3 & 2.3 & 2.2 & 2.1 & 2.0 \\
\hline Primary structural balafuce & -2.0 & -1.3 & 1.0 & 0.5 & 0.4 & 0.3 & 1.1 & 1.7 & 1,6 & 1.5 \\
\hline Fiscal impulse 4! & -0.3 & -0.7 & -2.3 & 0.5 & 0.2 & 0.1 & -0.8 & -0.6 & 0.1 & 0.0 \\
\hline Public debt & 69.2 & 69.1 & 64.7 & 63.9 & 64.7 & 62.9 & 62.1 & 59.9 & 57.7 & 55.8 \\
\hline \multicolumn{11}{|l|}{ Memorandura itern: } \\
\hline Output gap $\$ I$ & -0.6 & -0.8 & -1.6 & -0.8 & -0.6 & 0.0 & -0.5 & -0.4 & -0.2 & -0.2 \\
\hline
\end{tabular}

Sources: Austrian Statistical Office; Ministry of Finance; Austrian Stability Progrard; and DMF staff projections.

1/ On ESA95 basis.

2/ Subsidized lending minus repayments. Adjustment made in achordange with GFS methodology.

3/ Transactions considered as negative expenditure by Eurostat.

4/ Negative of the change in the primary structural balance.

$5 /$ In perceat of potential ofDP. 
Table 4. Austria: Indicators of Financial Vulnerability

(In percent of GDP, unless otherwise indicated)

\begin{tabular}{|c|c|c|c|c|c|c|}
\hline & \multirow[b]{2}{*}{1997} & \multirow[b]{2}{*}{1998} & \multirow[b]{2}{*}{1999} & \multirow[b]{2}{*}{2000} & \multicolumn{2}{|c|}{2001} \\
\hline & & & & & Latest & Date \\
\hline \multicolumn{7}{|l|}{ Public sector } \\
\hline Gerleral government balance $1 /$ & -1.7 & -2.3 & -2.1 & -1.1 & -0.72 & \\
\hline Structural balance $3 t$ & -1.9 & -2.3 & -2.2 & -2.0 & $-1.22 /$ & \\
\hline Public sector debt $\mathrm{V} /$ & 64.7 & 63.9 & 64.7 & 62.9 & $62.12 /$ & \\
\hline Extrabudgetary debt $4 /$ & 11.8 & 12.0 & 12.3 & $\ldots$ & $\ldots$ & \\
\hline Federal government guarantees & 28.6 & 28.4 & 29.0 & $\cdots$ & $\cdots$ & \\
\hline \multicolumn{7}{|l|}{ Financial sector } \\
\hline Growth rate of credit to the priqate sector $5 / 6 /$ & 3.6 & 3.7 & 5.2 & 6.7 & 1.1 & January \\
\hline Stock market index (level) $7 /$ & 129.5 & 112.1 & $\llbracket 19.8$ & 107.3 & 121.2 & May \\
\hline Price-earnings ratio 8 & 15.0 & 10.9 & 15.4 & 14.0 & 14.1 & May \\
\hline Foreign exchange loans & 8.8 & 12.8 & 16.8 & 19.2 & 18.3 & February \\
\hline \multicolumn{7}{|l|}{ Foreign exchange loans, share of } \\
\hline total loans $6 /$ & 8.3 & 12.2 & 15.7 & 17.5 & 17.5 & February \\
\hline Deposits in foreign exchange 6 & 6.3 & 5.6 & 1.6 & 1.6 & 1.5 & February \\
\hline \multicolumn{7}{|l|}{ Deposits in foreign exchange, share in } \\
\hline totai deposits $6 /$ & 7.3 & 6.4 & 1.8 & 1.9 & 1.8 & February \\
\hline Risk-based capital asset ratio, total & 12.9 & 14.3 & 13.9 & 13.8 & 14.2 & February \\
\hline Risk-based capital asset ratio, core capital & 9.0 & 9.8 & 9.4 & 9.1 & 9.4 & February \\
\hline
\end{tabular}

Sources: OeNB; Datastream; Bloomberg; Ministry of Finance; and IMF staff projections.

1/ European System of Accounts, 1995 (ESA 95).

$2 /$ Staff projections.

$3 /$ General government deficit according to ESA 95 adjusted for cyclical effects, one "off measures

(e.g., asset sales), and net subsidized lending.

4/ Debt of government owned enterprises.

5/ Excluting financial institutions and foreigners.

6/ Donestic nonbanks.

7/ For ATX index (1991=100) data refer to end of year.

8/ Price-earnings ratio for ATX. 
Total area

Total population GDP pet capita $\{2000$
83,850 squarc kilometers

8.08 million

US\$24.941 $\mathrm{l}$

\begin{tabular}{|c|c|c|c|c|c|c|c|}
\hline & 1996 & 1997 & 1998 & 1999 & 2000 & $2001 \mathrm{ll}$ & $20021 /$ \\
\hline & \multicolumn{7}{|c|}{ (Percentage changes at 1995 prices) } \\
\hline \multicolumn{8}{|l|}{ Demand, supply and saring } \\
\hline Private consumption & 3.2 & 1.4 & 2.9 & 2.3 & 2.7 & 2.3 & 2.5 \\
\hline Public consurnption $2 /$ & 1.2 & .1 .4 & 2.8 & 3.2 & 2.3 & 0.0 & 0.0 \\
\hline Gross fixed investment & 2.2 & 1.0 & 2.7 & 3.2 & 2.9 & 3.1 & 3.2 \\
\hline Construction & 0.3 & .2 .0 & 0.9 & 2.2 & 1.2 & 2.5 & 2.0 \\
\hline Machinery and equipment & 4.7 & 5.3 & 4.5 & 4.8 & 5.0 & 4.0 & 5.0 \\
\hline Inventrory accumulation $3 /$ & -0.6 & 0.6 & -0.4 & -0.1 & 0.2 & 0.0 & 0.1 \\
\hline Total domestic demand & 1.9 & 1.3 & 2.5 & 2.6 & 2.9 & 2.0 & 2.2 \\
\hline Exports of goods and nenfactor services & 6.2 & 9.9 & 5.5 & 7.6 & 9.8 & 5.0 & 5,4 \\
\hline Imports of goods and nonfactor services & 5.8 & 9.7 & 3.7 & $T_{2} 1$ & 9.2 & 4.5 & 4.8 \\
\hline Foreign balance 3 / & 0.1 & 0.0 & 0.8 & 0.2 & 0.3 & 0.2 & 0.4 \\
\hline GDP & 2.0 & 1,3 & 3.3 & 2.8 & 3.2 & 2.2 & 2.6 \\
\hline Real disposable income & 3.0 & 0.9 & 3.5 & 1.9 & 3.1 & 3.3 & 2,6 \\
\hline \multirow[t]{2}{*}{ Personal gaving ratio } & 8.8 & 8.1 & 8.8 & 8.6 & 8.4 & 8.6 & 8.8 \\
\hline & \multicolumn{7}{|c|}{ (Percent changes; period averages) } \\
\hline \multicolumn{8}{|l|}{ Employment and unemoployment } \\
\hline Labot foted $4 /$ & -0.2 & 0.3 & 0.8 & 0.5 & 0.0 & 0.2 & 0.2 \\
\hline Employitient 4 & -0.7 & 0.3 & 0.6 & 0.9 & 1.0 & 0.2 & 0.4 \\
\hline \multicolumn{8}{|l|}{ Unempkyment tare (in percent) } \\
\hline Registered $5 f$ & 6.3 & 6.4 & 6.5 & 6.0 & 5.2 & 5.4 & 5.4 \\
\hline Standardized $S t$ & 4,3 & 4.4 & 4.5 & 3.9 & 3.7 & 3.6 & 3.5 \\
\hline \multicolumn{8}{|l|}{ Prices and ineomes } \\
\hline GDP deflator & 1.3 & 12 & 0.7 & 0.9 & 12 & 1.0 & 1.7 \\
\hline Conșumęr price index & 1.8 & 1.2 & 0.8 & 0.5 & 2.0 & 1.7 & 1.6 \\
\hline Gross compensation per employed person & 2.7 & 5.5 & 3.4 & 4.2 & 3.5 & 3,0 & 3.0 \\
\hline Unit labor costs (mmufacturing) & $-1,0$ & -4.0 & -0.7 & -0.5 & -0.5 & -0.5 & 0.5 \\
\hline
\end{tabular}

1/ Staff estimates and projections.

2 Due to the adoption of EU conventions for national accounts statistics, public consumption increased by 1.5 percent in 1996 (abolition of VAT on health services) and fell abour 4.75 percent in 1997 (reclassiffeation of public hospitals).

3/ Change as percent of previous year's GDP

4/ Dependent labor force (dines not include self-employed).

5/In percent of total labor force. The standardized rate is survey-based aceording to EU stardards. 
Austria: Basic Data (concluded)

\begin{tabular}{|c|c|c|c|c|c|c|c|}
\hline & 1996 & 1997 & 1998 & 1999 & 2000 & 200111 & $2002 \mathrm{~V}$ \\
\hline & \multicolumn{7}{|c|}{ (In percent of GDP) } \\
\hline \multicolumn{8}{|l|}{ Public flnances } \\
\hline \multicolumn{8}{|l|}{ Geticral goverument } \\
\hline Expenditure & 56,6 & 53.8 & 54.2 & 53.6 & 51.8 & 51.9 & 50.5 \\
\hline Revenue & 52.8 & 52.1 & 51.9 & 51.5 & 50.7 & 51.2 & 50.5 \\
\hline Financial balance & -3.8 & -1.7 & -2.3 & -2.1 & -1.1 & -0.7 & 0.0 \\
\hline \multicolumn{8}{|l|}{ Of which } \\
\hline Federal government & $-4,0$ & -2.7 & -2.9 & -2.4 & -1.4 & -1.4 & -0.7 \\
\hline Other levels of government & 0.2 & 1.0 & 0.6 & 0.3 & 0.3 & 0.7 & 0.7 \\
\hline \multicolumn{8}{|l|}{ Gross deb! (cnd of period) } \\
\hline Federal government & 61.1 & 58.6 & 58.1 & 59.3 & 57.9 & 56.9 & 54.5 \\
\hline \multirow[t]{2}{*}{ General government } & 69,2 & 64.7 & 63.9 & 64.6 & 62.9 & 62.1 & 59,9 \\
\hline & \multicolumn{7}{|c|}{ (In billions of schillings) } \\
\hline \multicolumn{8}{|l|}{ Balance of payments } \\
\hline Trade balance & $-77,0$ & -52.0 & -45.3 & -46.5 & -39.7 & -33.5 & -28.5 \\
\hline Current account & -57.5 & -79.2 & -64.5 & -85.4 & -80.9 & .79 .8 & -67.1 \\
\hline \multirow[t]{2}{*}{ (In pereent of GDP) } & -2.3 & -3.2 & -2.5 & -3.2 & -2.9 & -2.7 & -2.2 \\
\hline & \multicolumn{7}{|c|}{ (Percent) } \\
\hline \multicolumn{8}{|l|}{ Interest rates and credit } \\
\hline Domcstic credit to nonbanks (percent change, top) $2 /$ & 3.6 & 3.6 & 3.7 & 5.2 & 6.7 & 6.2 & $\ldots$ \\
\hline Three-month interbank rate 3 i & 3.4 & 3.5 & 3.5 & 3.0 & 4.4 & 4,8 & $\ldots$ \\
\hline \multirow[t]{2}{*}{10 -year government bond 37} & 6.3 & 5.7 & 4.7 & 4.7 & 5.6 & 5.3 & $\ldots$ \\
\hline & \multicolumn{7}{|c|}{ (Levels, period averages) } \\
\hline \multicolumn{8}{|l|}{ Excbange rates } \\
\hline Schillings per USS 31 & 10.6 & 12.2 & 12.4 & 12.9 & 14.9 & 15.5 & $\ldots$ \\
\hline Euro per US $\$ 3 y$ & ... & $\ldots$ & $\ldots$ & 0.9 & 1.1 & 1.1 & $\cdots$ \\
\hline Nominal effective exchange Jate 4 & 105.3 & 102.9 & 103.1 & 102,1 & 99.9 & 100.3 & $\ldots$ \\
\hline Real effective exchange rate & & & & & & & $\ldots$ \\
\hline ULC based 4/ & 88.2 & 83.6 & 81.9 & 80.0 & 77.8 & 77.4 & $\ldots$ \\
\hline CPI based $5 /$ & 106.0 & 102.3 & 102.3 & 100,4 & 97.7 & 98.5 & $\cdots$ \\
\hline
\end{tabular}

W/ Staff estimates and projections.

2/ For 2001, data refer to January 2001.

3/ For 2001, deta refer to May 8, 2001.

4/ For 2001, data refer to April 2001.

5/ For 2001, data refer to February 2001. 


\section{Austria: Fund Relations}

(As of March 31, 2001)

\section{Membership Status:}

(a) Date of membership: August 27, 1948.

(b) Status: Article VIII, as from August 1, 1962.

II. General Resources Account:

SDR Million

Quota

Fund holdings of currency

Reserve position in Fund

Financial Transaction Plan transfers (net)
$1,872.30$

$1,339.61$

532.67

69.00

III. SDR Department:

SDR Million

Net cumulative allocation

Holdings

179.05

125.28

100.0

70.0

IV. Outstanding Purchases and Loans: None

V. Financial Arrangements: None

VI. Projected Obligations to Fund: None

VII. Austria has not used Fund resources.

VIII. Exchange System:

As of January 1, 1999, the currency of Austria is the euro. In cash transactions, however, the Austrian schilling remains legal tender until 2002, when euro notes and coins will be issued. Each euro is equivalent to AS 13.7603.

Austria's exchange system is free of restrictions on the making of payments and transfers for international transactions. However, Austria maintains exchange restrictions against Iraq pursuant to U.N. Security Council Resolution No. 661. These restrictions were notified to the Fund under Decision No. 144.

\section{Last Article IV Consultation}

Discussions for the 2000 Article IV consultation were held in Vienna during May 15-23, 2000. The staff report (SM/00/95) was discussed by the Executive Board on August 3, 2000. 


\section{Austria: Statistical Issues}

For the purpose of surveillance, the timeliness of Austrian data should be improved by bringing them up to "best practice" in Europe with regard to national accounts data, industrial production, the (accrual based) current account, and merchandise trade. Compared to Germany and France, for instance, the publication of these data lags by about one month.

The transition to the new European Standard of Accounts (1995) has complicated the analysis of Austrian national accounts as the new national account data provide no data on household disposable income (only an economy-wide aggregate), barring the calculation of a household saving ratio. In addition, the reclassification of public hospitals in 1997 has introduced a break in the national account series on public and private consumption. Fiscal data from 1995, compiled in accordance with 1995 ESA, are not complete. From 1995, expenditure by function and financing and debt data have not yet been reported for inclusion in the GFS Yearbook.

A large difference between the data on goods trade recorded by the statistical office (Statistics Austria) and the payments data recorded by the National Bank has given rise to significant problems in assessing the developments in the foreign trade balance and the current account in the recent years (data on accrual basis are only available with a long time lag). Data based on the fifth edition of the Balance of Payments Manual are only available back to 1992.

Austria has subscribed to the Fund's Special Data Dissemination Standard (SDDS), and Austrian metadata are available on the Fund's electronic Dissemination Standards Bulletin Board. Austria has taken advantage of the flexibility options on the timeliness of the industrial production index and merchandise trade data. The authorities have indicated that financing data for General Government Operations for the year 2000 will be disseminated with the prescribed timeliness of six months by the end of June 2001 . 
Austria: Core Statistical Indicators 1/

As of May 10, 2001

\begin{tabular}{|c|c|c|c|c|c|c|c|}
\hline & $\begin{array}{l}\text { Industrial } \\
\text { Production }\end{array}$ & $\begin{array}{l}\text { Consumer Price } \\
\text { Index } \\
\end{array}$ & Exports/ Imports & $\begin{array}{c}\text { Current Account } \\
\text { Balance 2/ }\end{array}$ & $\begin{array}{c}\text { Overall } \\
\text { Government } \\
\text { Balance 3/ }\end{array}$ & GDP/GNP & External Debt \\
\hline $\begin{array}{c}\text { Date of Latest } \\
\text { Observation }\end{array}$ & $02 / 01$ & $03 / 01$ & $01 / 01$ & $02 / 01$ & 2000 & $00 \mathrm{Q} 4$ & 1999 \\
\hline Date Received & $5 / 02 / 01$ & $4 / 19 / 01$ & $4 / 10 / 01$ & $4 / 23 / 01$ & $4 / 10 / 01$ & $4 / 02 / 01$ & $1 / 24 / 01$ \\
\hline Frequency of Data & Monthly & Monthly & Monthly & Monthly & Annual & Quarterly & Annual \\
\hline Frequency of Reporting & Monthly & Monthly & Monthly & Monthly & Annual & Quarterly & Annual \\
\hline Source of Update & Statistics Austria & Statistics Austria & Statistics Austria & OeNB & MoF & WTFO & OeNB \\
\hline Mode of Reporting & Intemet & Electronic & Internet & Internet & Internet & Email & Internet \\
\hline Confidentiality & None & None & None & None & None & None & None \\
\hline $\begin{array}{r}\text { Frequency of } \\
\text { Publication }\end{array}$ & Monthly & Monthly & Monthly & Monthly & Annual & Annual & Annual \\
\hline
\end{tabular}

OeNB = Austrian National Bank

WIFO = Austrian Institute of Economic Research

$\mathrm{MoF}=$ Federal Ministry of Finance

1/ Austria is a member of the European Monetary Union. Exchange rates, foreign reserves, the central bank balance sheet, interest rates and other monetary indicators are published by the European Central Bank.

2/ Cash basis.

3/ National accounts basis 
This page intentionally left blank

(CInternational Monetary Fund. Not for Redistribution 


\section{INTERNATIONAL MONETARY FUND}

EXTE[RNAL

\section{Public Information Notice}

Public Information Notice (PIN) No. 01/58 FOR IMMEDIATE RELEASE

June 13, 2001

International Monetary Fund

$70019^{\text {th }}$ Street, NW

Washington, D. C. 20431 USA

\section{IMF Concludes Article IV Consultation with Austria}

On June 11, 2001, the Executive Board of the International Monetary Fund (IMF) concluded the Article IV consultation with Austria. ${ }^{1}$

\section{Background}

After a vigorous expansion in late 1999-early 2000, growth in the Austrian economy decelerated in mid-2000 in tandem with weaker activity in Europe, bringing annual real GDP growth to 3.2 percent in 2000 . Resilient private consumption is projected to support growth at about 2.2 percent this year. The labor market is tight, with unemployment stable at about 3.7 percent. Although headline inflation rose to 2.5 percent in April, it continues to remain below the euro area average.

Fiscal consolidation has taken new momentum with the authorities' revised 2001-04 Stability Program. After 3 years of broadly neutral fiscal policy, the 2001-02 federal budgets, together with savings measures by the lower levels of govemment, envisage a cumulative structural fiscal adjustment of about 1.5 percent of GDP, bringing the general government budget to balance by 2002 .

Privatization of state holdings in commercial enterprises has continued, and liberalization of the electricity and gas markets is planned to be completed well ahead of EU deadlines. The labor market has performed well, with solid employment growth and greater emphasis on active labor market policies helping to reduce unemployment among most target groups, especially older, long-term unemployed and female workers. However, progress with rationalizing market regulation, streamlining administrative requirements, and liberalizing access to the professions

\footnotetext{
' Under Article IV of the IMF's Articles of Agreement, the IMF holds bilateral discussions with members, usually every year. A staff team visits the country, collects economic and financial information, and discusses with officials the country's economic developments and policies. On return to headquarters, the staff prepares a report, which forms the basis for discussion or review by the Executive Board. At the conclusion of the discussion or review, a summary is transmitted to the country's authorities. This PIN summarizes the views of the Executive Board review.
} 
has been slow, and labor force participation of older workers remained one of the lowest in Europe.

\section{Executive Board Assessment}

Executive Directors endorsed the thrust of the staff appraisal, commending the authorities for the achievement of strong growth, falling unemployment, and low inflation. Although there were no acute economic problems and the outlook was reasonably bright, Directors considered that longer-term policy challenges remained. They welcomed the recent fiscal policy correction and steps to liberalize utilities, but noted that a large public sector with a high tax burden, an underfunded social security system, and a heavily regulated economy cloud the horizon.

Against the background of persistent government deficits, high public debt, and one of the highest expenditure ratios in the $\mathrm{EU}$, Directors stressed that the plan to reach general govemment balance by 2002 was an important step toward sound public finances. The already legislated 2001 and 2002 federal budgets were seen as consistent with this objective. The next step was to conclude the agreement on the contribution of the lower levels of government to the adjustment and to ensure that consolidation at the lower levels represented genuine fiscal reforms and avoided recourse to expenditure reclassification.

Directors expressed concern as to the sustainability of the proposed adjustment. The lack of structural fiscal reforms risked future fiscal backsliding, and heavy reliance on surpluses by the lower government levels to reach general govemment balance could jeopardize reaching the objective if cooperation by the lower levels could not be secured or expenditure classification rules changed. In addition, strict adherence to a "zero deficit" on a year-to-year basis would likely require procyclical measures and adoption of a structural fiscal balance target would be preferable.

In light of pressures to reduce the tax burden and narrow the scope of the public sector's direct economic involvement, Directors recommended a longer-term focus in the fiscal policy debate and encouraged the authorities to proceed with the adoption of a comprehensive civil service and administrative reform, with a view to permanently shrinking the size of government.

Directors stressed that long-term fiscal sustainability called for changes to the pension system. Temporary fiscal surpluses, while mitigating the problem, were no substitute for comprehensive pension reform. As delaying such reform would ultimately require more painful adjustment, the authorities were urged to formulate their pension reform plans and implement reform measures.

The authorities were urged to implement their unfinished structural agenda to meet the challenges from international competition. Removal of regulatory and other impediments to competition and flexibility in the product, capital and labor markets were crucial in the absence of an independent monetary policy to deal with increasing competition from abroad, including from future EU enlargement. The authorities were encouraged to complete the first phase of their privatization program and not to delay launching its second phase; pursue liberalization and regulatory reform in the product markets more vigorously and shorten legislative and 
implementation lags for initiatives already in the pipeline; and stimulate labor supply and ease rigidities in the labor market to prepare for the consequences of population aging.

Directors noted that the growing internationalization of the financial sector, especially the growing activity by Austrian banks in Central and Eastern Europe, required continued vigilance by the supervisors. The planned reform of financial supervision should focus on strengthening its effectiveness, without compromising its full independence. In order not to weaken regulatory capacity in the changeover to the new supervisory arrangement, the transition would need to be carefully managed.

Austria was encouraged to strengthen its efforts to alleviate world poverty and stimulate international trade by raising its official development assistance toward the UN target and using its influence in the EU to promote market access for the exports of developing countries, promote agricultural reform in the EU, and liberalize world trade in agricultural products and services under the auspices of the WTO.

Austria's data provision was considered to be adequate for surveillance, although the timeliness of some statistics could be improved.

Public Information Notices (PINs) are issued, (i) at the request of a member country, following the conclusion of the Article IV consultation for countries seeking to make known the views of the IMF to the public. This action is intended to strengthen IMF surveillance over the economic policies of member countries by increasing the transparency of the IMF's assessment of these policies; and (ii) following policy discussions in the Executive Board at the decision of the Board. The staff report for the 2001 Article IV Consultation with the country name is also available. 
Austria: Selected Economic Indicators

\begin{tabular}{|c|c|c|c|c|c|}
\hline & 1997 & 1998 & 1999 & 2000 & $2001^{1}$ \\
\hline \multicolumn{6}{|l|}{ Real economy (change in percent) } \\
\hline GDP & 1.3 & 3.3 & 2.8 & 3.2 & 2.2 \\
\hline Domestic demand & 1.3 & 2.5 & 2.6 & 2.9 & 2.0 \\
\hline CPI (year average) & 12 & 0.8 & 0.5 & 2.0 & 1.7 \\
\hline Unemployment rate (in percent) & 4.4 & 4.5 & 3.9 & 3.7 & 3.6 \\
\hline Gross national saving (percent of GDP) & 20.8 & 21.5 & 20.8 & 21.2 & 21.4 \\
\hline Gross domestic investment (percent of GDP) & 23.9 & 24.0 & 23.9 & 24.0 & 24.1 \\
\hline \multicolumn{6}{|l|}{ Public finance (percent of GDP) } \\
\hline Central government balance & -2.7 & -2.9 & -2.4 & -1.4 & -1.4 \\
\hline General government balance & -1.7 & -2.3 & -2.1 & -1.1 & -0.8 \\
\hline General government debt & 64.7 & 63.9 & 64.7 & 62.9 & 62.1 \\
\hline \multicolumn{6}{|l|}{$\begin{array}{l}\text { Money and credit } \\
\text { (end of year, percent change) }\end{array}$} \\
\hline Domestic credit & 3.6 & 3.7 & 5.2 & 6.7 & $\ldots$ \\
\hline M3 & 1.2 & 6.4 & 4.7 & 5.6 & $\cdots$ \\
\hline \multicolumn{6}{|l|}{ Interest rates (in percent) } \\
\hline Money market rate ${ }^{23}$ & 3.5 & 3.5 & 3.0 & 4.4 & 4.8 \\
\hline Government bond yield ${ }^{4}$ & 5.7 & 4.7 & 4.7 & 5.6 & 5.3 \\
\hline \multicolumn{6}{|l|}{ Balance of payments (percent of GDP) ${ }^{5}$} \\
\hline Trade balance & -2.1 & -1.7 & -1.7 & -1.4 & -1.1 \\
\hline Current account & -3.2 & -2.5 & -3.2 & -2.9 & -2.7 \\
\hline \multicolumn{6}{|l|}{ Fund position (as of March 31,2001 ) } \\
\hline Holdings of currency (in percent of quota) & & & $1,339.61$ & & \\
\hline Holdings of SDRs (in percent of allocation) & & & 125,28 & & \\
\hline Quota (in millions of SDRs) & & & $1,872.30$ & & \\
\hline \multicolumn{6}{|l|}{ Exchange rate } \\
\hline Exchange rate regime & \multicolumn{3}{|c|}{ Member of euro area } & & \\
\hline Euros per U.S. dollar (April 20, 2001) & $\ldots$ & $\ldots$ & 0.94 & 1.08 & 0.91 \\
\hline Nominal effective rate $(1990=100)$ & 102.9 & 103.1 & 102.1 & 99.9 & 100.3 \\
\hline Real effective rate $(1990=100)^{6}$ & 83.6 & 81.9 & 80.0 & 77.8 & 77.4 \\
\hline
\end{tabular}

Sources: Intemational Financial Statistics; Austrian National Bank; Austrian Statistical Office; and Fund staff projections.

"MF staff projections.

${ }^{2}$ Refers to euro rate beginning in 1999.

${ }^{3}$ For 2001 , data refer to May 8.

4 For 2001, average of the first [three] month\$s.

${ }^{5}$ On a transaction basis.

${ }^{6}$ Based on relative normalized unit labor costs In manufacturing. 